\title{
Kisspeptin Directly Excites Anorexigenic Proopiomelanocortin Neurons but Inhibits Orexigenic Neuropeptide Y Cells by an Indirect Synaptic Mechanism
}

\author{
Li-Ying Fu and Anthony N. van den Pol \\ Department of Neurosurgery, Yale University School of Medicine, New Haven, Connecticut 06520
}

The neuropeptide kisspeptin is necessary for reproduction, fertility, and puberty. Here, we show strong kisspeptin innervation of hypothalamic anorexigenic proopiomelanocortin (POMC) cells, coupled with a robust direct excitatory response by POMC neurons $(n>200)$ to kisspeptin, mediated by mechanisms based on activation of a sodium/calcium exchanger and possibly opening of nonselective cation channels. The excitatory actions of kisspeptin on POMC cells were corroborated with quantitative PCR data showing kisspeptin receptor GPR54 expression in the arcuate nucleus, and the attenuation of excitation by the selective kisspeptin receptor antagonist, peptide 234. In contrast, kisspeptin inhibits orexigenic neuropeptide Y (NPY) neurons through an indirect mechanism based on enhancing GABAmediated inhibitory synaptic tone. In striking contrast, gonadotropin-inhibiting hormone (GnIH and RFRP-3) and NPY, also found in axons abutting POMC cells, inhibit POMC cells and attenuate the kisspeptin excitation by a mechanism based on opening potassium channels. Together, these data suggest that the two central peptides that regulate reproduction, kisspeptin and GnIH, exert a strong direct action on POMC neurons. POMC cells may hypothetically serve as a conditional relay station downstream of kisspeptin and GnIH to signal the availability of energy resources relevant to reproduction.

\section{Introduction}

Energy homeostasis and reproduction are intimately related. Here, we examine the interface between the kisspeptin and gonadotropin-inhibiting hormone $(\mathrm{GnIH})$ neurons that regulate reproduction, and the proopiomelanocortin (POMC) and neuropeptide Y (NPY) neurons that regulate energy homeostasis. Kisspeptin (metastin) and its receptor, GPR54, are considered essential gatekeepers of puberty onset and fertility in mammals (Dhillo, 2008). Kisspeptin knock-out mice are infertile (d'Anglemont de Tassigny et al., 2007). Mutations in GPR54 result in disruption of reproductive function in both humans and mice (de Roux et al., 2003; Seminara et al., 2003). Kisspeptin stimulates gonadotropin-releasing hormone $(\mathrm{GnRH})$ release (Gottsch et al., 2004; Shahab et al., 2005) and excites GnRH neurons (Han et al., 2005; Dumalska et al., 2008; Liu et al., 2008), but cannot stimulate luteinizing hormone secretion in GPR54 knock-out mice (Messager et al., 2005).

In contrast, a neuropeptide that opposes the actions of kisspeptin, GnIH, inhibits gonadotropin release (Tsutsui et al., 2000; Tsutsui, 2009) and hyperpolarizes and blocks kisspeptin excitation of gonadotropin neurons (Ducret et al., 2009; Wu et al., 2009). GnIH actions were selective for GnRH neurons, and no effect on septal GABAergic or cholinergic neurons was detected.

Received April 23, 2010; revised June 14, 2010; accepted June 17, 2010.

This work was supported by National Institutes of Health Grants NS48476, NS34887, and NS41454. We thank Y. Yang and V. Rogulin for helpful technical assistance and G. Wollmann for artistic facilitation.

Correspondence should be addressed to Anthony N. van den Pol, Department of Neurosurgery, Yale University School of Medicine, 333 Cedar Street, New Haven, CT 06520. E-mail: anthony.vandenpol@yale.edu.

D0I:10.1523/JNEUROSCI.2098-10.2010

Copyright $\odot 2010$ the authors $\quad$ 0270-6474/10/3010205-15\$15.00/0
Injections of $\mathrm{GnIH}$ into the brain increase food intake (Tachibana et al., 2005, 2008; Johnson et al., 2007).

POMC neurons located in the arcuate nucleus are important anorexigenic regulators of energy homeostasis (Boston, 2001). POMC neurons are suggested to decrease food intake by releasing peptides such as $\alpha$-MSH that activate the MC3/MC4 melanocortin receptors (Cowley et al., 2001; Heisler et al., 2003; Hill et al., 2008). Deleting the gene for POMC-related peptides results in obesity (Yaswen et al., 1999). NPY neurons in the arcuate nucleus play an orexigenic role in energy homeostasis (Wang et al., 1997). Long-distance energy signals leptin and insulin may inhibit feeding by activating POMC neurons, while depressing NPY neurons in the arcuate nucleus (Elias et al., 1999; Schwartz et al., 2000; Cowley et al., 2001; Elmquist, 2001). Reproduction is dependent on a positive energy balance. Metabolic stress and energy insufficiency have frequently been coupled to disturbed reproductive maturation and/or infertility. Obesity is also commonly linked to altered puberty onset and reproductive impairment (FernandezFernandez et al., 2006; Castellano et al., 2009). Kisspeptin neurons may also participate in transmitting metabolic information to the GnRH neurons (Tena-Sempere, 2006; Roa et al., 2008; Castellano et al., 2009). Fasting reduces kisspeptin mRNA expression (Castellano et al., 2005; Luque et al., 2007; Brown et al., 2008), which precedes the fasting-induced decline of GnRH. Both kisspeptin mRNA and gonadotropins are decreased in diabetic or starved animals.

Kisspeptin is synthesized by neurons in the hypothalamic arcuate and anteroventral periventricular nuclei, and found in local axons within the arcuate nucleus (Gottsch et al., 2004; Brailoiu et al., 2005). The mRNA of its receptor, GPR54, is also found in the 
arcuate nucleus (Lee et al., 1999; Mikkelsen and Simonneaux, 2009), raising the question of whether kisspeptin modulates the activity of arcuate neurons. Here, we studied the electrophysiological effects of kisspeptin on POMC and NPY neurons: Kisspeptin excited POMC neurons directly by mechanisms based on enhancing sodium-calcium exchange and opening nonselective cation channels, while inhibiting NPY cells indirectly by enhancing presynaptic GABA release. GnIH immunoreactive axons innervated POMC neurons, and $\mathrm{GnIH}$ attenuated the actions of kisspeptin on POMC neurons.

\section{Materials and Methods}

Preparation of hypothalamic slices. Slices containing the hypothalamic arcuate nucleus were obtained from transgenic mice that selectively express enhanced green fluorescent protein (GFP) in POMC-containing neurons (kindly provided by Dr. M. Low, Oregon Health and Science University, Portland, OR), as reported previously (Cowley et al., 2001; Batterham et al., 2002; Acuna-Goycolea and van den Pol, 2005) or from transgenic mice expressing a Renilla GFP selectively in NPY cells (van den Pol et al., 2009). Briefly, 14- to 60-d-old male and female mice maintained in a 12:12 h light/dark cycle were deeply anesthetized by administering an overdose of sodium pentobarbital (100 mg/kg, i.p.) during the light phase of the cycle (10:00 A.M. to 2:00 P.M.). The brains were then rapidly removed and placed in an ice-cold oxygenated $\left(95 \% \mathrm{O}_{2}, 5 \%\right.$ $\mathrm{CO}_{2}$ ) high-sucrose solution containing the following (in $\mathrm{mM}$ ): $220 \mathrm{su}$ crose, $2.5 \mathrm{KCl}, 6 \mathrm{MgCl}_{2}, 1 \mathrm{CaCl}_{2}, 1.23 \mathrm{NaH}_{2} \mathrm{PO}_{4}, 26 \mathrm{NaHCO}_{3}, 10$ glucose, pH 7.4 (when equilibrated with the mixed $\mathrm{O}_{2}$ ). A tissue block containing the mediobasal hypothalamus was prepared, and coronal slices (250-300 $\mu \mathrm{m}$ thick) were cut on a vibratome in sucrose solution. The slices were gently moved to an equilibrium chamber filled with gassed, artificial CSF (ACSF) $\left(95 \% \mathrm{O}_{2}, 5 \% \mathrm{CO}_{2}\right)$ that contained the following (in mM): 124 $\mathrm{NaCl}, 3 \mathrm{KCl}, 2 \mathrm{MgCl}_{2}, 2 \mathrm{CaCl}_{2}, 1.23 \mathrm{NaH}_{2} \mathrm{PO}_{4}, 26 \mathrm{NaHCO}_{3}$, and 10 glucose, $\mathrm{pH}$ 7.4. After a 1-2 $\mathrm{h}$ recovery period, slices were moved to a recording chamber mounted on an Olympus BX51WI upright microscope equipped with video-enhanced, infrared-differential interference contrast (DIC) and fluorescence and perfused with a continuous flow of gassed ACSF. Neurons were viewed using blue excitation light with an Olympus $40 \times$ water-immersion lens. The use of mice for these experiments was approved by the Yale University Committee on Animal Use.

Patch-clamp recording. Whole-cell current- and voltage-clamp recordings were performed using pipettes with $4-6 \mathrm{M} \Omega$ resistance after filling with pipette solution. Recording pipettes were made of borosilicate glass (World Precision Instruments) using a PP-83 vertical puller (Narishige) or with a P-97 Flaming/Brown micropipette puller (Sutter Instrument). For most recordings, the composition of the pipette solution was as follows (in mM): $130 \mathrm{KMeSO}_{4}$ (or $\mathrm{KCl}$ for IPSCs and mIPSCs), $1 \mathrm{MgCl}_{2}$, 10 HEPES, 1.1 EGTA, $2 \mathrm{Mg}$-ATP, and $0.5 \mathrm{Na}_{2}$-GTP, $10 \mathrm{Na}_{2}$-phosphocreatine, $\mathrm{pH} 7.3$ with $\mathrm{KOH}$. For some experiments, Cs-based pipette solution was used, which contains the following: $130 \mathrm{CsMeSO}_{4}, 1 \mathrm{MgCl}_{2}$, 10 HEPES, 1.1 EGTA, $2 \mathrm{Mg}$-ATP, and $0.5 \mathrm{Na}_{2}$-GTP, $10 \mathrm{Na}_{2}$ phosphocreatine, $\mathrm{pH} 7.3$ with $\mathrm{CsOH}$. POMC neurons in the arcuate nucleus were initially identified under fluorescence, and then DIC was used to get a seal in these cells. After a gigaohm seal was obtained, a gentle negative pressure was applied to break through to the whole-cell configuration. An EPC10 amplifier and Patchmaster software (HEKA Elektronik) were used for data acquisition. Slow and fast capacitance were compensated automatically using Patchmaster software. Input resistance was monitored continuously, and only those cells with a stable access resistance (change $<10 \%$ ) were used for analysis. The recordings were made at $32^{\circ} \mathrm{C}$.

Pulsefit (HEKA Electronik), Axograph (Molecular Devices), and Igor Pro (Wavemetrics) software were used for analysis. Both miniature and spontaneous postsynaptic currents were detected and measured with an algorithm in Axograph (Bekkers and Stevens, 1995), and only those events with amplitude $>5 \mathrm{pA}$ were used. The frequency of action potentials was measured using Axograph as well. In Results, data are expressed as mean \pm SE unless otherwise noted. ANOVA with Bonferroni's post hoc test, $t$ test, and Kolmogorov-Smirnov statistical tests were used. A value of $p<0.05$ was considered statistically significant. The membrane potential values were compensated to the liquid junction potential of +9.5
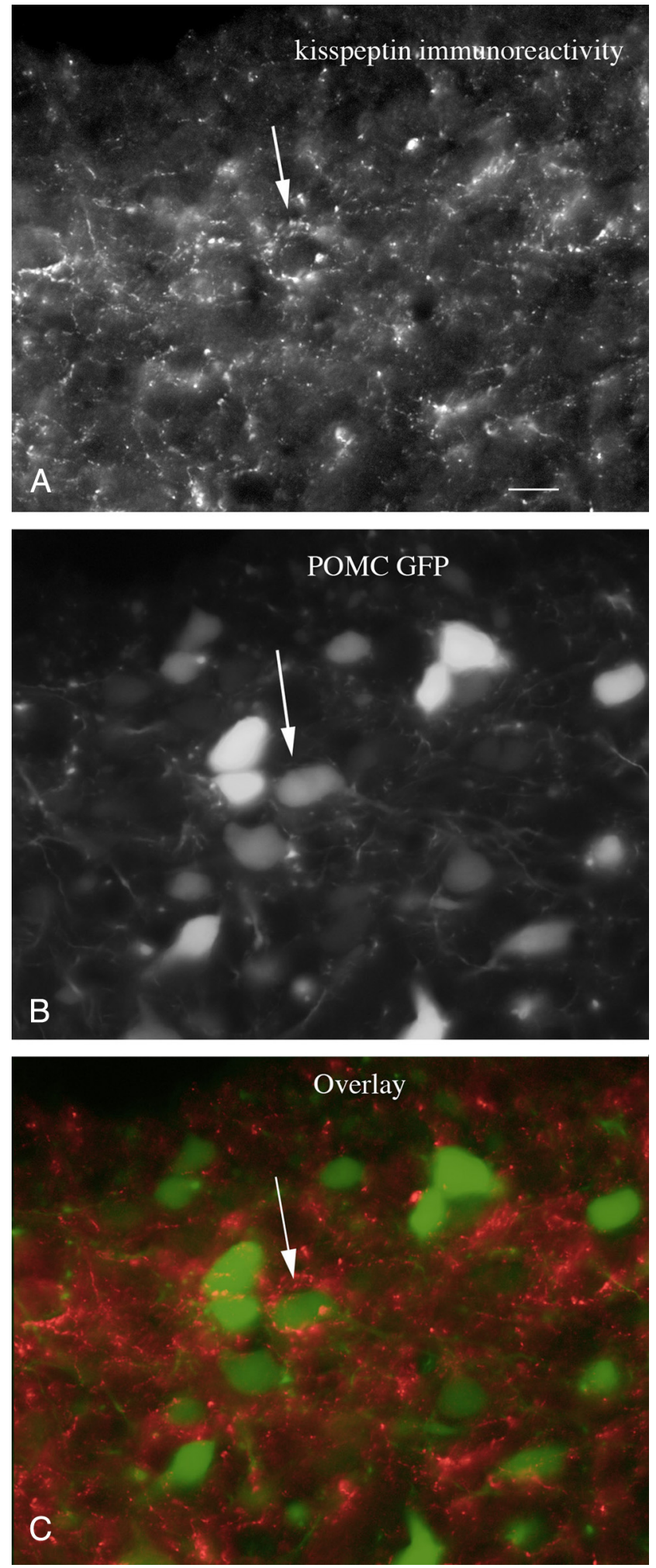

Figure 1. Kisspeptin-immunoreactive axons terminate near POMC neurons. $A$, A strong innervation by kisspeptin-immunoreactive axons is found in the arcuate nucleus. Scale bar, 12 $\mu \mathrm{m}$. $\boldsymbol{B}$, In the same field as in $\boldsymbol{A}$, GFP-expressing POMC neurons are found. $\boldsymbol{C}$, The arrows indicate kisspeptin-immunoreactive axons and boutons terminating near or on POMC neurons.

$\mathrm{mV}$ when $\mathrm{KMeSO} 4$ pipette solution was used. In some experiments, the initial potential was shifted by injection of a small negative current to stabilize the cells. The spike frequency, membrane potential, and current values used as control values were the mean values from 1 to 2 min of 

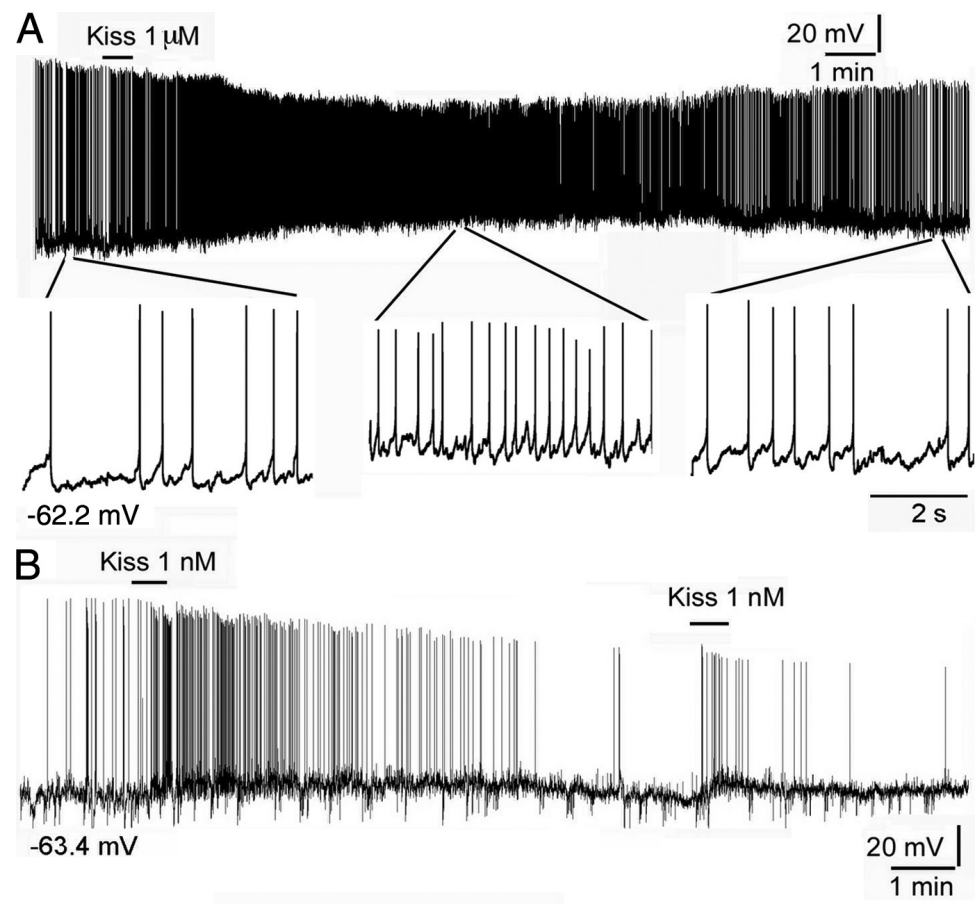

C

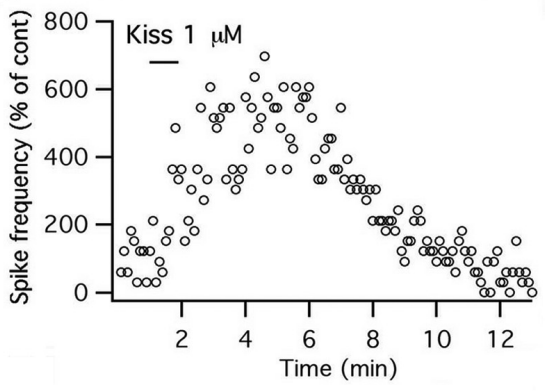

E

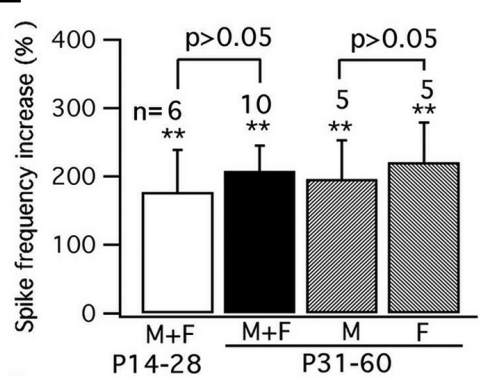

$\mathrm{G}$

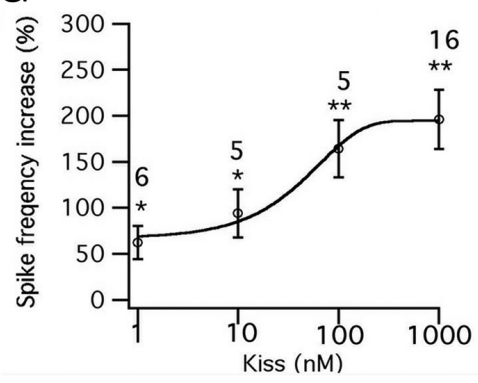

D

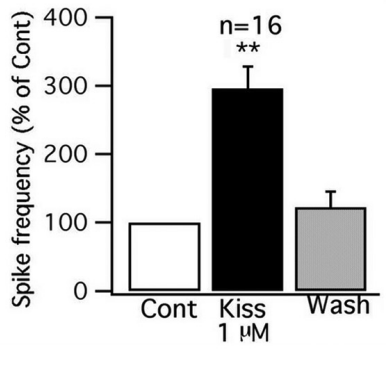

F

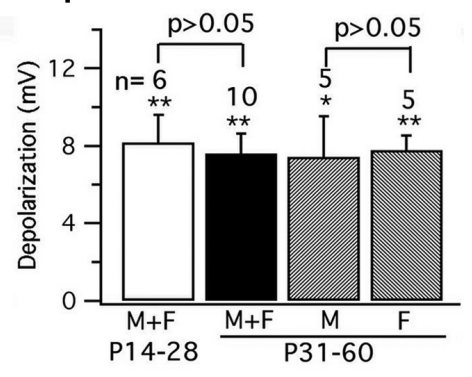

$\mathrm{H}$

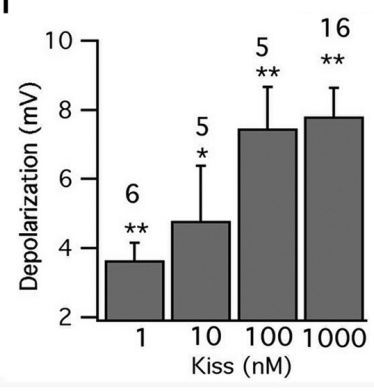

Figure 2. Kisspeptin excites POMC neurons. A, A trace showing that kisspeptin (1 $\mu \mathrm{M})$ excited POMC neurons, with segments of the trace amplified below. $\boldsymbol{B}$, Trace showing excitation of $1 \mathrm{~nm}$ kisspeptin on POMC cells, and this effect was repeated by a second application of kisspeptin on the same cell. C, Time course of the effect of kisspeptin on the POMC cell shown in trace in A. D, Bar graph showing the reversible increase of kisspeptin on the spike frequency of POMC Cells with an average washout period of $10 \mathrm{~min}$. $\boldsymbol{E}$, Kisspeptin $(1 \mu \mathrm{m})$ increases spike frequency in POMC cells in male and female mice at different ages. $\boldsymbol{F}$, Depolarization of POMC stable recording before drug application, depending on the experiment. Changes after applying kisspeptin or other peptides were also the mean value of a 1-2 min stable period when the maximal effect was reached.

Immunocytochemistry. To determine whether substances we tested physiologically might be released by axon terminals near recorded cells, we combined immunocytochemistry with detection of GFP in male and female adult POMC-GFP mice. Rabbit antisera against kisspeptin that has been characterized (Franceschini et al., 2006; Lapatto et al., 2007) was used at 1:10,000-1:50,000 (generous gift from Dr. I. Franceschini, CNRS, Nouzilly, France, and purchase from Millipore) $(n=5$ mice $)$. NPY antiserum was used at 1:3000 (Bachem) $(n=3$ mice). A well characterized $\mathrm{GnIH}$ antiserum (Kriegsfeld et al., 2006) was kindly provided by Dr. George Bentley (University of California, Berkeley, CA $)$ and was used at 1:3000 $(n=4$ mice). After treatment with $0.3 \%$ Triton X-100 for $1 \mathrm{~h}, 16$ - to $30-\mu \mathrm{m}$-thick sections cut on a vibratome or cryostat were incubated overnight in primary antiserum. Secondary goat or donkey anti-rabbit conjugated to rhodamine, Texas Red, or Alexa 594 from Invitrogen was used at 1:150 to $1: 300$ for $1-2 \mathrm{~h}$. Sections were examined with an Olympus IX70 fluorescent microscope, and photographs were taken with a Spot digital camera. Micrographs were corrected with respect to contrast and density using Adobe Photoshop.

Quantitative real-time PCR. Region-specific mouse brain tissue samples were microdissected from 250 - to $300-\mu \mathrm{m}$-thick brain slices (harvested as described in the section on electrophysiological methods), and total RNA was extracted from each sample using the RNeasy Micro kit (QIAGEN). Total RNA was reverse transcribed with qScript cDNA SuperMix (Quanta Biosciences). Quantitative PCR (qPCR) was performed in 96-well dishes on an iCycler iQ Multicolor Real-Time Detection System (Bio-Rad) using TaqMan Gene Expression Assays catalog \#Mm00475046_m1 Gpr54 (ABI). The results were normalized to $\beta$-actin expression using the Endogenous Control Assay (ABI; part no. 4352933E), mouse ACTB FAM Dye/MGB probe, nonprimer limited, amplicon size of 115 bp. qPCRs were performed using TaqMan Gene Expression Master Mix (ABI) according to the manufacturer's protocol.

Chemicals and reagents. Kisspeptin (human metastin 45-54 amide, KiSS-1, or mouse kisspep-

$\leftarrow$

cells by kisspeptin $(1 \mu \mathrm{M})$ in male and female mice at different ages. $\mathbf{G}$, The dose-dependent effect of kisspeptin on spike frequency of POMC cells. $\boldsymbol{H}$, Bar graph showing the depolarization of membrane after application of kisspeptin from $1 \mathrm{~nm}$ to $1 \mu \mathrm{M}$. ${ }^{*} p<0.05,{ }^{* *} p<0.01$ versus control analyzed by ANOVA. The statistical tests used in comparing different ages or genders are grouped $t$ tests. The number of cells tested is shown above the bars in $\boldsymbol{E}-\boldsymbol{H}$. The membrane potential values under the traces in $\boldsymbol{A}$ and $\boldsymbol{B}$ indicate the membrane potentials before applying kisspeptin. Error bars indicate SEM. 

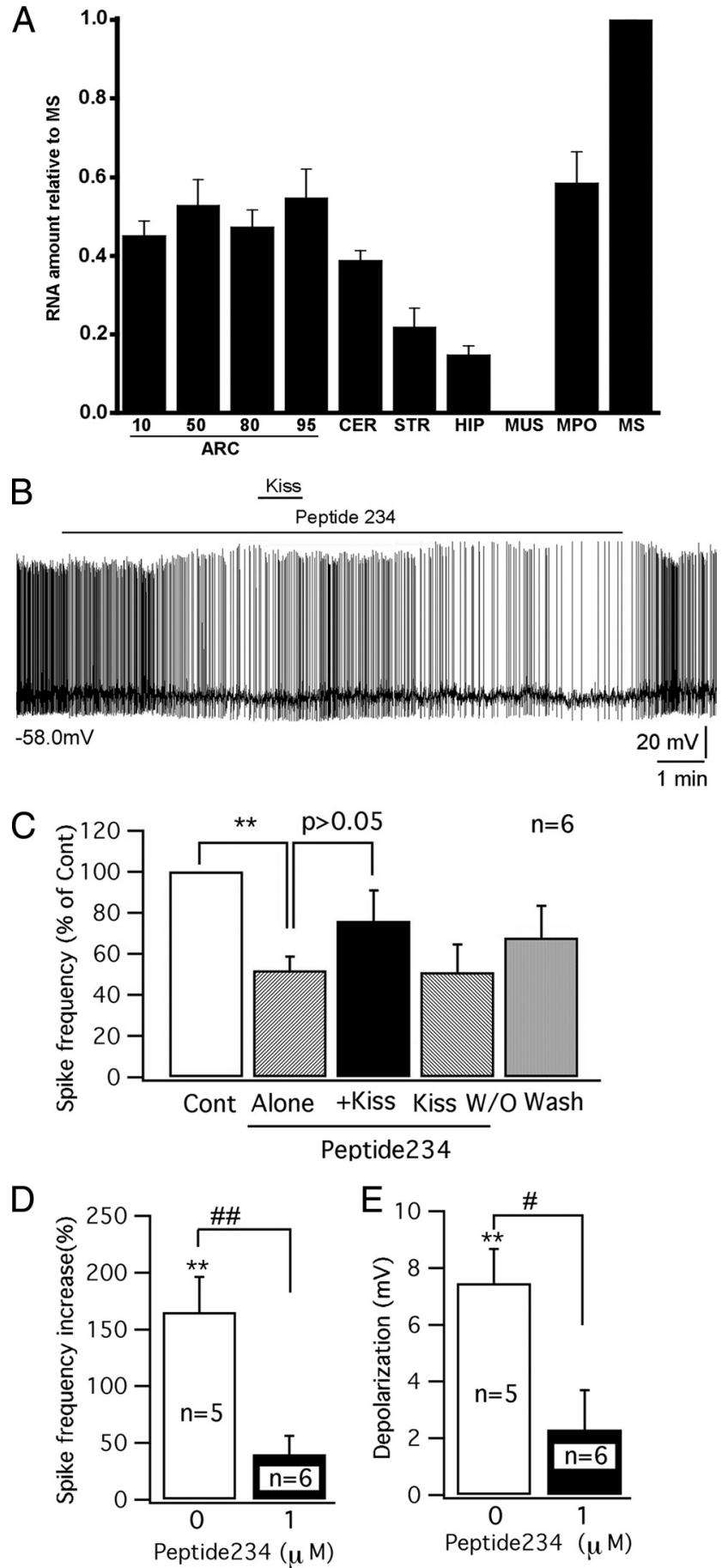

Figure 3. GPR54 receptor antagonist peptide 234 inhibits the excitation of kisspeptin on POMC cells. $\boldsymbol{A}$, A bar graph based on qPCR shows relative levels of GPR54 mRNA in several brain areas and in muscle (MUS), consistent with previous reports (Lee et al., 1999; Mikkelsen and Simonneaux, 2009). Four levels of the ARC were sampled, rostral to caudal (numbers show deciles in position from rostral to caudal, with 10 being in the rostralmost $10 \%$ of the arcuate nucleus, and 100 being in the caudalmost region of the nucleus). All regions of the arcuate nucleus expressed kisspeptin receptor mRNA. CER, Cerebellum; STR, striatum; HIP, hippocampus; MPO, medial preoptic area; MS, medial septum; MUs, muscle. The bars represent means; most bars are based on samples from four mice, each analyzed independently, with ARC10 and ARC 95 based on three mice and muscle based on two mice. The flags are SEM. CT for MS was 29.4 for GRP54 and 21.7 for actin. $\boldsymbol{B}$, A trace showing the firing of a POMC cell in the presence of peptide $234(1 \mu \mathrm{m})$ and kisspeptin (Kiss) (100 nM). Initial membrane potential is shown under the trace. C, Bar graph showing the change in spike frequency after applying peptide 234 (1 $\mu \mathrm{m})$ alone, kisspeptin (Kiss) (100 nm) with peptide 234 (1 $\mu \mathrm{m})$, kisspeptin washout (Kiss W/0), and ACSF washout. D, Bar graph comparing the increase of spike frequency by kisspeptin (100 nm) tin), bicuculline methiodiode (BIC), DL-2-amino-5-phosphonovaleric acid (AP5), 6-cyano-7-nitroquinoxaline-2,3-dione (CNQX), cadmium chloride $\left(\mathrm{CdCl}_{2}\right)$, and 1,2-bis(o-aminophenoxy)ethane- $N, N, N^{\prime}, N^{\prime}$ tetra-acetic acid (BAPTA) were purchased from Sigma-Aldrich. NPY (human, rat, mouse), GnIH (chicken), and RFamide-related peptide-3 (RFRP-3) (human) were from Phoenix Pharmaceuticals. Tetrodotoxin (TTX), 1-[2-(4-methoxyphenyl)-2-[3-(4-methoxyphenyl)propoxy] ethyl-1 $\mathrm{H}$ imidazole hydrochloride (SKF96365), 2-[2-[4-(4-nitrobenzyloxy) phenyl]ethyl]isothiourea mesylate (KB-R7943), 2-[[4-[(4-nitrophenyl) methoxy]phenyl]methyl]-4-thiazolidinecarboxylic acid ethyl ester (SN-6), and (S)-3,5-dihydroxyphenylglycine (DHPG) were obtained from Tocris Bioscience. Lithium chloride ( $\mathrm{LiCl}$ ) was from Acros Organics. Peptide 234 was synthesized by the Keck Biotechnology Resource Center of Yale University.

Kisspeptin, GnIH, RFRP-3, and DHPG were applied focally to the recorded neurons via a large $400 \mu \mathrm{m}$ tip diameter flow pipe. When drugs were not applied, a continuous flow of buffer was supplied from the flow pipe. KB-R7943, SN-6, SKF96365, and peptide 234 were applied in the continuous flow of buffer as well as with kisspeptin when the cells were pretreated with these chemicals. TTX, AP5, CNQX, BIC, $\mathrm{CdCl}_{2}$, and $\mathrm{BaCl}_{3}$ were applied in the bath.

\section{Results}

Kisspeptin-immunoreactive axons surround POMC neurons Immunocytochemical staining with antisera against kisspeptin revealed a high density of immunoreactive axons in the mouse arcuate nucleus, confirming previous reports (Franceschini et al., 2006; Lapatto et al., 2007). We examined the relationship of kisspeptin-immunoreactive fibers labeled with red fluorescence with POMC neurons that expressed the reporter gene for GFP. Many green POMC cells (Fig. $1 B$ ) were surrounded by red kisspeptin-immunoreactive fibers (Fig. $1 A, C$ ), suggesting that the released peptide would be in an anatomical position to influence the POMC cell. Having identified a close anatomical juxtaposition of kisspeptin axonal boutons near POMC neurons, we used a neurophysiological approach to determine whether kisspeptin had any effect on the POMC cells.

\section{Kisspeptin excites POMC neurons}

Whole-cell patch-clamp recordings were undertaken from identified GFP-tagged POMC neurons located in the arcuate nucleus of acute brain slices. The effect of kisspeptin on POMC neurons was studied. Kisspeptin excited POMC cells. With current-clamp recording, kisspeptin $(1 \mathrm{nM}$ to $1 \mu \mathrm{M})$ increased the spike frequency and depolarized the membrane potential of POMC cells dose-dependently (Fig. 2A-H); typical of frequent spikes associated with a sustained depolarization, the spike amplitude was reduced over time (Fig. 2A,B). After application of kisspeptin (1 $\mu \mathrm{M}$ ) for $1 \mathrm{~min}$, the spike frequency of POMC cells (from mice $14-60 \mathrm{~d}$ old $)$ was increased by $196 \pm 32 \%(p<0.01 ; n=16$; ANOVA), and the membrane potential was depolarized by $7.8 \pm$ $0.8 \mathrm{mV}$ from the starting membrane potential of $-57.6 \pm 0.9 \mathrm{mV}$ $(p<0.01 ; n=16$; ANOVA) (Fig. $2 C-H)$. The effect of kisspeptin was compared in mice grouped by different ages and gender. In mice aged 31-60 d, kisspeptin $(1 \mu \mathrm{M})$ increased the spike frequency by $196 \pm 57 \%(p<0.01 ; n=5$; ANOVA $)$ in male mice and by $221 \pm 58 \%(p<0.01 ; n=5$; ANOVA $)$ in female mice, with no significant difference between two groups $(p>0.05 ; n=$ $10 ; t$ test). The membrane potential was depolarized by $7.4 \pm 2.1$

with and without the pretreatment of peptide $234(1 \mu \mathrm{M})$. $\boldsymbol{E}$, Bar graph comparing the depolarization induced by kisspeptin ( $100 \mathrm{~nm}$ ) with and without the pretreatment of peptide 234 (1 $\mu \mathrm{M}) .{ }^{* *} p<0.01 ; n=6$; paired $t$ test. ${ }^{\#} p<0.05 ;{ }^{\# \#} p<0.01$; group $t$ test. 
$\mathrm{mV}(p<0.05 ; n=5$; ANOVA $)$ in male mice and by $7.8 \pm 0.8 \mathrm{mV}$ $(p<0.01 ; n=5$; ANOVA $)$ in female mice without significant difference between genders ( $p>0.05 ; n=10$; $t$ test) (Fig. $2 E, F)$.

When the data for adult male and female mice aged 31-60 d was pooled to form one group, the increase in spike frequency was $208 \pm 37 \%(p<0.01 ; n=10$; ANOVA $)$ and the membrane potential depolarization was $7.6 \pm 1.0 \mathrm{mV}(p<0.01 ; n=6$; ANOVA) (Fig. 2E, F). We compared these means to immature mice aged at 14-28 d. In six mice (three males and three females) aged from 14 to $30 \mathrm{~d}$, kisspeptin $(1 \mu \mathrm{M})$ increased the spike frequency of POMC cells by $177 \pm 62 \%(p<0.01 ; n=6$; ANOVA $)$ and depolarized the membrane potential by $8.2 \pm 1.4 \mathrm{mV}(p<$ $0.01 ; n=6$; ANOVA). There was no statistical difference between adults and immature mice ( $p<0.05 ; n=16$; t test) (Fig. $2 E, F)$. Below, we pool all data from mice of different gender and ages together.

The effect of kisspeptin was long-lasting in most cells, and spike frequency recovered after a washout averaging $10 \mathrm{~min}$ (spike frequency, $124 \pm 24 \%$ vs control; and membrane potential, $3.0 \pm 0.3 \mathrm{mV}$ vs control) (Fig. $2 D$ ). To examine the possibility of desensitization, in 10 cells that were excited by kisspeptin (from $1 \mathrm{nM}$ to $1 \mu \mathrm{M}$ ), after the membrane potential and firing status recovered to the control level after peptide washout, we applied the same concentration of kisspeptin again to the same POMC cells. In 7 of these 10 cells, the second application of kisspeptin also evoked an excitatory effect, but with a smaller depolarization compared with the first effect; the second application of kisspeptin did not depolarize three cells. The membrane potential change after the first and second application was compared in all 10 cells (first depolarization, $4.7 \pm 1.1 \mathrm{mV}$; second, $1.1 \pm 0.4 \mathrm{mV} ; p<0.05$; $t$ test) (Fig. $2 B$ ), suggesting that the response to kisspeptin does desensitize.

We used both human and mouse kisspeptin-10 that differ by one amino acid. Since both kisspeptins gave similar results, data were pooled; previous in vivo work in mice also showed similar responses to human and mouse kisspeptin (Mikkelsen et al., 2009).

To minimize the disturbance of the intracellular environment during recording, cell-attached recording was also used to investigate the effect of kisspeptin on POMC neurons. Kisspeptin (1 $\mu \mathrm{M})$ increased the frequency of the action currents of POMC neurons by $252 \pm 85 \%(p<0.05 ; n=6$; ANOVA $)$ with cellattached recording. This is consistent with the effect of kisspeptin on spike frequency of POMC neurons obtained by whole-cell recording, suggesting that, with both whole-cell recording and the resultant perfusion of the intracellular milieu, and with cellattached recording in which the intracellular ionic composition is not altered, kisspeptin excited POMC neurons.

GPR54 receptors are expressed in arcuate nucleus POMC cells and mediate the excitation of kisspeptin

Previous reports have shown kisspeptin receptors in the arcuate nucleus (Lee et al., 1999; Mikkelsen and Simonneaux, 2009), but the reporter gene lac $Z$, regulated by the kisspeptin receptor gene promoter in a knock-in mouse, showed no expression in the arcuate nucleus (Herbison et al., 2010). To further investigate the expression of kisspeptin receptor mRNA in the arcuate nucleus, we used quantitative reverse transcription-PCR in the mouse brain. We found strong kisspeptin receptor expression in the medial preoptic area and medial septum where $\mathrm{GnRH}$ neurons are found, and also found expression in all rostrocaudal regions of the arcuate nucleus, and lower levels in the hippocampus, striatum, and cerebellum (Fig. $3 A$ ). In contrast, muscle, used as a negative control, showed no expression. These data support the
In TTX+AP5+CNQX+BIC

A

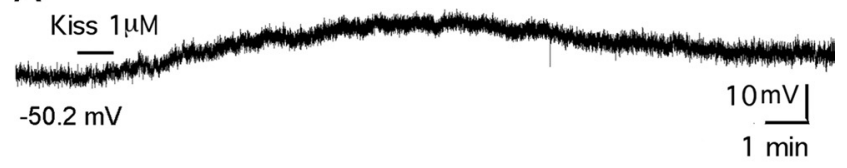

B1

B3
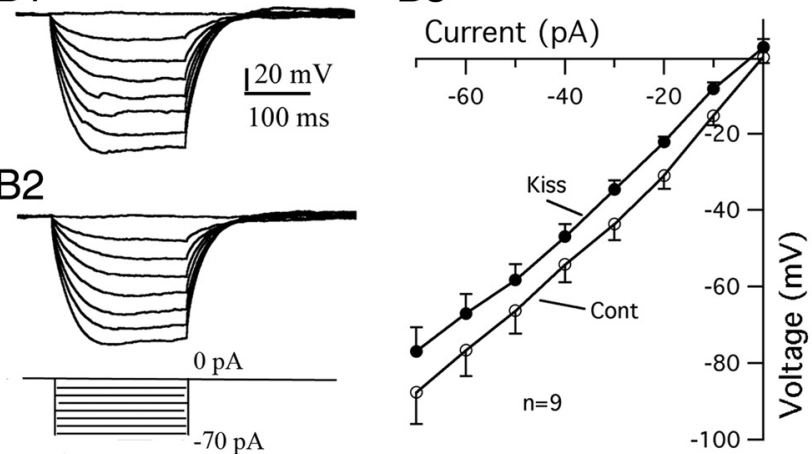

In BIC

C
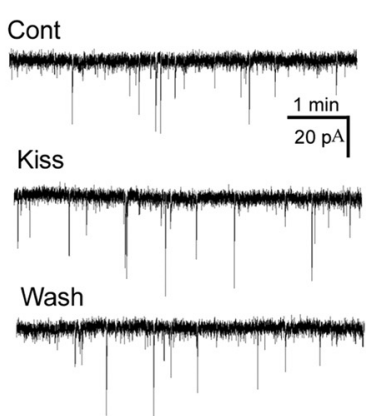

In AP5+CNQX

$\mathrm{E}$

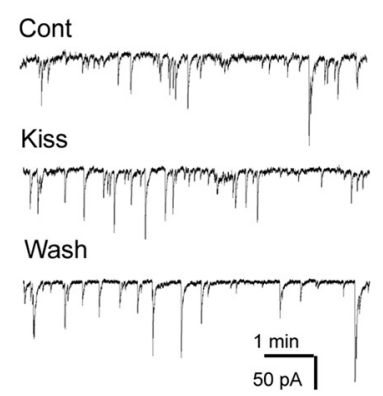

$\mathrm{D}$

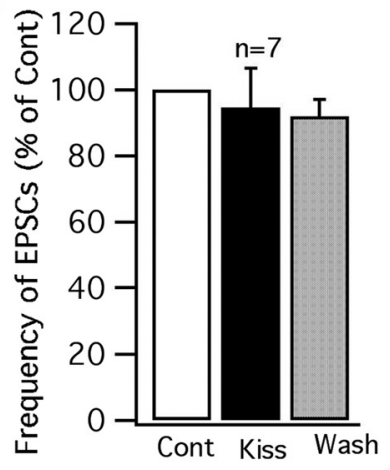

$\mathrm{F}$

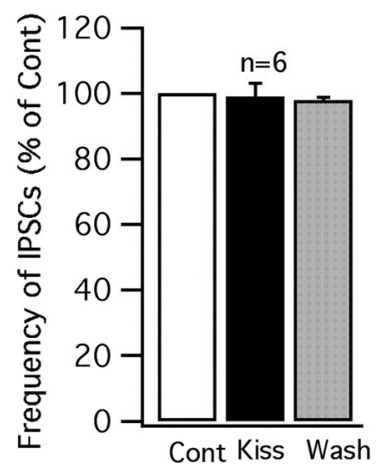

Figure 4. Direct effect of kisspeptin on POMC neurons. $A$, In the presence of TTX (0.5 $\mu \mathrm{M}), \operatorname{AP5}(50 \mu \mathrm{M}), \mathrm{CNQX}(10 \mu \mathrm{M})$, and BIC (30 $\mu \mathrm{M})$, kisspeptin (1 $\mu \mathrm{m})$ depolarized a POMC cell. The membrane potential value under the trace indicates the membrane potential before applying kisspeptin. $\boldsymbol{B} 1-\boldsymbol{B}$, Responses of a POMC cell to current injection from -70 to $0 \mathrm{pA}$ before $(\boldsymbol{B} 1)$ and during $(\boldsymbol{B} 2)$ application of kisspeptin $(1 \mu \mathrm{M})$ and the current-voltage relationship of POMC cells before and during kisspeptin (1 $\mu \mathrm{M})(B 3)$. C, Spontaneous EPSCs of a POMC cell during control, kisspeptin $(1 \mu \mathrm{M})$, and washout period. EPSCs were recorded at a holding potential of $-60 \mathrm{mV}$ in the presence of BIC $(30 \mu \mathrm{M})$. $D$, Bar graph showing that kisspeptin does not change the frequency of EPSCs. E, Spontaneous IPSCS of a POMC cell during control, kisspeptin $(1 \mu \mathrm{M})$, and washout period. IPSCs were recorded at a holding potential of $-60 \mathrm{mV}$ in the presence of AP5 (50 $\mu \mathrm{M})$ and CNQX (10 $\mu \mathrm{M}) . \boldsymbol{F}$, Bar graph showing that kisspeptin does not change the frequency of IPSCs. Error bars indicate SEM. 


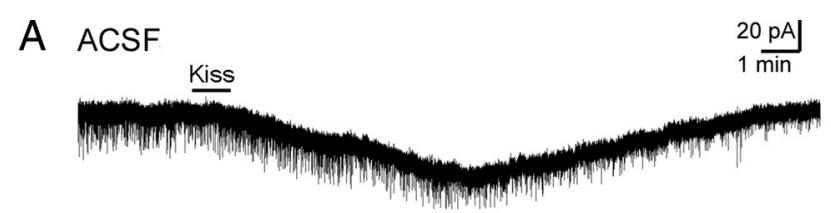

B $0 \mathrm{Ca}^{2+} / 10 \mathrm{Mg}^{2+}$

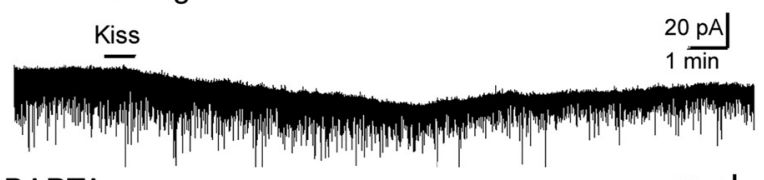

C BAPTA

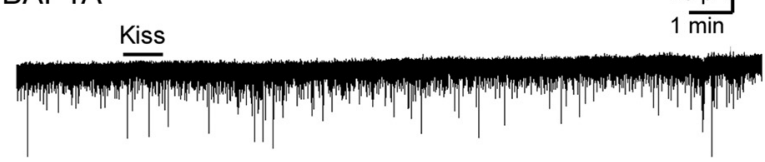

D $\mathrm{Li}^{+}$-ACSF

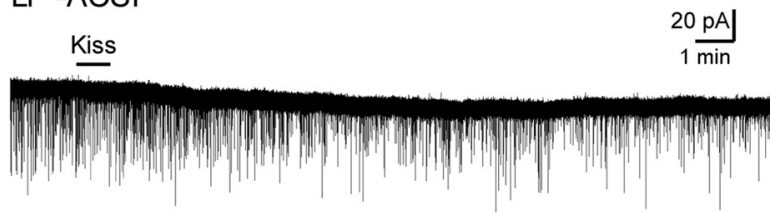

E KB-R7943

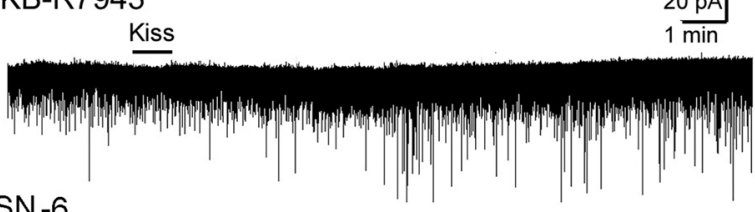

F SN-6

Kiss

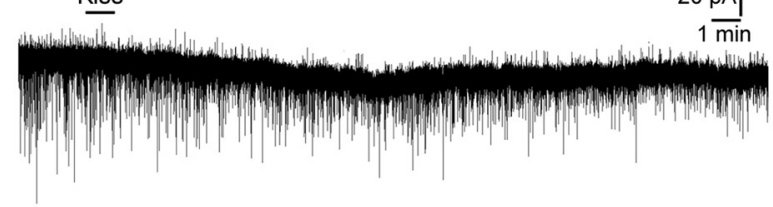

G SKF-96365
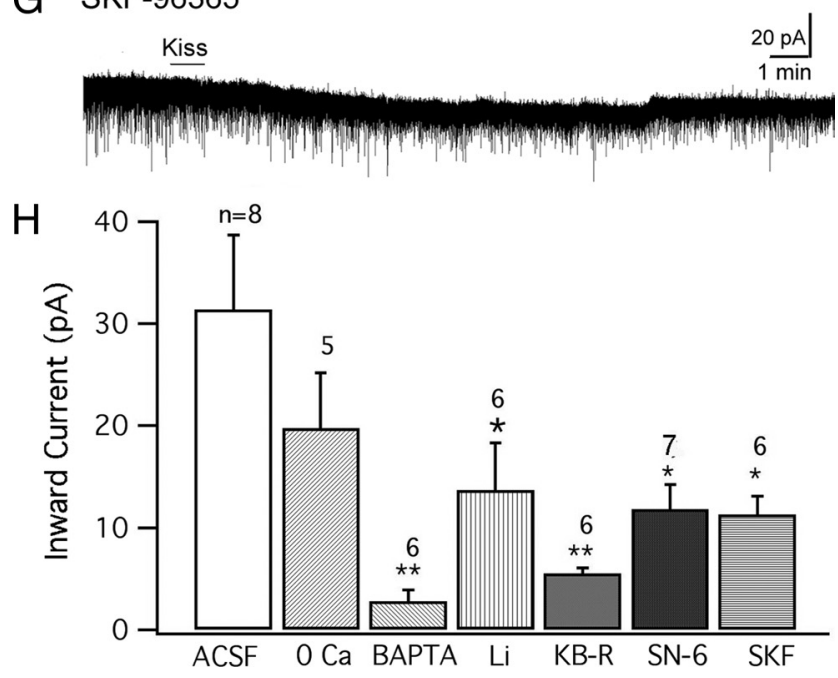

Figure 5. Kisspeptin induces an inward current in POMC cells. The inward current was recorded at a holding potential of $-60 \mathrm{mV}$ with TTX $(0.5 \mu \mathrm{M})$ in the bath. $\boldsymbol{A}$, Kisspeptin (1 $\mu \mathrm{M})$ evoked an inward current in a POMC neuron in normal ACSF. $\boldsymbol{B}$, The inward current induced by kisspeptin $(1 \mu \mathrm{m})$ in nominal zero- $\mathrm{Ca}^{2+} / 10 \mathrm{~mm} \mathrm{Mg}{ }^{2+}$ ACSF solution. C, The kisspeptin induced inward current in a POMC neuron was blocked with BAPTA $(10 \mathrm{~mm})$ in the pipette solution. $\boldsymbol{D}$, Inward current induced by kisspeptin on a POMC cell in an ACSF solution with $\mathrm{Na}^{+}$replaced by $\mathrm{Li}^{+}$. $\boldsymbol{E}$, The kisspeptin induced current on a POMC cell in the presence of NCX blocker KB-R7943 $(60 \mu \mathrm{M})$. $\boldsymbol{F}$, Kisspeptin induced current in a POMC cell in the presence of a more selective NCX blocker SN-6 (10 $\mu \mathrm{M})$. G, Kisspeptin $(1 \mu \mathrm{M})$ induced a small inward current in the presence of SKF96365 (10 $\mu \mathrm{M})$. $\boldsymbol{H}$, Bar graph showing the mean view that some neurons of the mouse arcuate nucleus do express the kisspeptin receptor mRNA.

To substantiate further that the excitation induced by kisspeptin in POMC cells was mediated by the GPR54 receptor, the recently identified kisspeptin antagonist peptide 234 was tested. Peptide 234 is a 10 aa peptide obtained by substituting amino acids of kisspeptin-10, the minimal sequence required for full GPR54 receptor binding and activation (Roseweir et al., 2009). Under current-clamp recording, after a stable control was obtained, peptide 234 was applied to POMC cells first and then kisspeptin was applied together with peptide 234. Interestingly, peptide $234(1 \mu \mathrm{M})$ alone inhibited POMC cells (Fig. 3B). After a 4 min application, peptide $234(1 \mu \mathrm{M})$ decreased the spike frequency of POMC cells by $48 \pm 6.7 \%(p<0.01 ; n=6$; paired $t$ test $)$ and showed a tendency to hyperpolarize the membrane potential (by $3.6 \pm 1.6 \mathrm{mV} ; p=0.07$; $n=6$; paired $t$ test) (Fig. $3 C$ ), suggesting tonic GPR54 receptor activity may be present in POMC cells.

In the presence of peptide $234,1 \mathrm{~min}$ application of kisspeptin $(100 \mathrm{~nm})$ showed a greatly decreased tendency to increase the spike frequency $(40 \pm 16 \% ; p=0.07 ; n=6$; paired $t$ test) and failed to depolarize the membrane potential significantly (by $2.3 \pm 1.4 \mathrm{mV} ; p>0.05 ; n=6$; paired $t$ test) (Fig. $3 C$ ). The effect of kisspeptin in the presence of peptide 234 was substantially smaller than the effect of application of kisspeptin in the absence of peptide 234 (spike frequency increase: $40 \pm 16$ vs $160 \pm 31 \%$, $p<0.01 ; n=11$; group $t$ test; $p<0.05$; membrane depolarization: $2.3 \pm 1.4$ vs $7.4 \pm 1.2 \mathrm{mV}, p<0.05 ; n=11$; group $t$ test) (Fig. $3 D, E$ ). These results suggest that kisspeptin excites POMC cells via activation of the GPR54 receptor and the antagonist reduces this activation.

Kisspeptin excites POMC cells via a direct postsynaptic effect The effect of kisspeptin was further investigated in the presence of TTX $(0.5 \mu \mathrm{M})$, to block spontaneous firing, and glutamate and GABA receptor antagonists AP5 $(50 \mu \mathrm{M})$, CNQX $(10 \mu \mathrm{M})$, and $\mathrm{BIC}(30 \mu \mathrm{M})$ to block presynaptic input. Under these conditions, kisspeptin $(1 \mu \mathrm{M})$ consistently depolarized the membrane potential of POMC neurons (Fig. $4 \mathrm{~A}$ ) with an average depolarization of $6.2 \pm 1.4 \mathrm{mV}$ from the starting membrane potential of $-55.3 \pm$ $2.7 \mathrm{mV}(p<0.01 ; n=7$; ANOVA). The current-voltage relationship before and after applying kisspeptin ( $1 \mu \mathrm{M})$ was obtained by injecting a series of square wave currents from -70 to 0 pA. The input resistance was calculated based on the linear part of the current-voltage relationship curve (Fig. 4B1-B3). Kisspeptin $(1 \mu \mathrm{M})$ modestly decreased the input resistance by $9 \pm 3.7 \%$ (control, $1200 \pm 129 \mathrm{M} \Omega$; kisspeptin, $1080 \pm 109 \mathrm{M} \Omega ; p<0.05$; $n=9$; paired $t$ test). These results suggest that kisspeptin modulates the POMC neurons via a direct postsynaptic mechanism.

We next investigated the effect of kisspeptin on spontaneous EPSCs and IPSCs in GFP-expressing POMC neurons. Spontaneous EPSCs were recorded using a $\mathrm{KMeSO}_{4}$ pipette solution with BIC $(30 \mu \mathrm{M})$ in the bath. Under these conditions, kisspeptin (1 $\mu \mathrm{M})$ did not change the frequency of EPSCs ( $95 \pm 12 \%$ of control; $p>0.05 ; n=7$; ANOVA) (Fig. 4C,D). In the presence of AP5 $(50 \mu \mathrm{M})$ and CNQX $(10 \mu \mathrm{M})$, spontaneous IPSCs were recorded at a holding potential of $-60 \mathrm{mV}$ using a $\mathrm{KCl}$ pipette solution. Similarly, kisspeptin $(1 \mu \mathrm{M})$ did not change the frequency of IPSCs ( $99 \pm 4 \%$ of control; $p>0.05 ; n=6$; ANOVA) (Fig.

$\leftarrow$

amplitude of kisspeptin induced current in POMC cells during different recording conditions. ${ }^{*} p<0.05$; ${ }^{* *} p<0.01$; group $t$ test. Error bars indicate SEM. 


\section{A $\mathrm{ACSF} / \mathrm{K}^{+}$pipette solution}
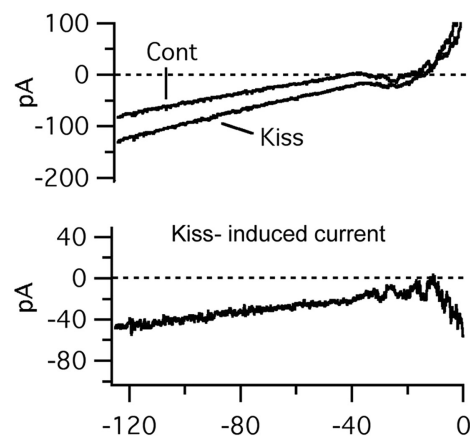

C $\mathrm{Li}^{+}-\mathrm{ACSF}$
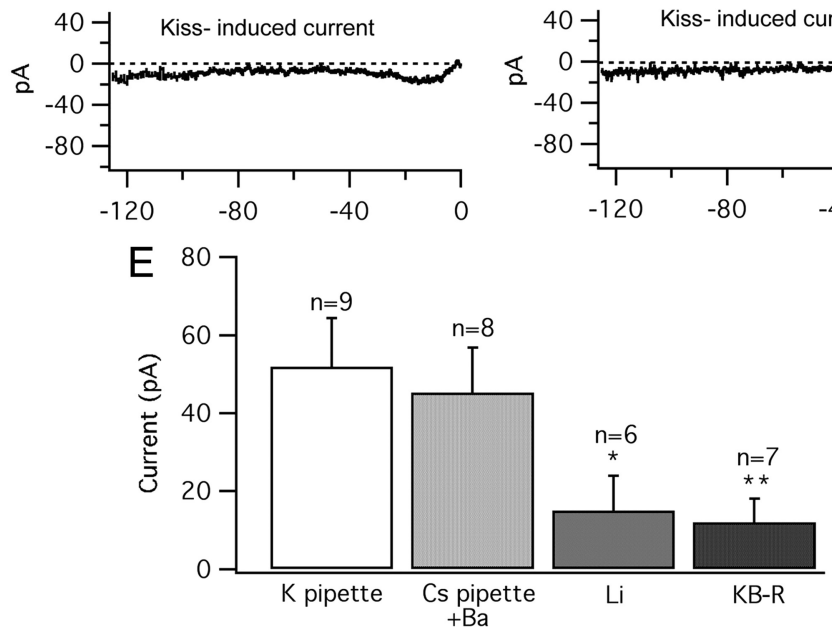

Figure 6. Kisspeptin-evoked current is attenuated by $\mathrm{Li}^{+}$and $\mathrm{KB}-\mathrm{R} 7943$. The current traces were evoked by voltage ramps from -130 to $0 \mathrm{mV}$ at a holding potential of $-60 \mathrm{mV}$. TTX $(0.5 \mu \mathrm{M}), \mathrm{AP5}(50 \mu \mathrm{M}), \mathrm{CNQX}(10 \mu \mathrm{M}), \mathrm{BIC}(30 \mu \mathrm{M})$, and $\mathrm{Cd}^{2+}(200 \mu \mathrm{M})$ were added in the bath solution. $A$, Recordings performed with a normal $\mathrm{ACSF}$ bath perfusion and a $\mathrm{KMeSO}_{4}$ pipette solution. Top, Traces showing the current responses to the voltage ramp in POMC cells before (Cont) and during kisspeptin (Kiss) (1 $\mu \mathrm{M}$ ). Bottom, The Kiss-induced current (subtraction of Cont from Kiss). B , Cont and Kiss (top) and Kiss-induced current (bottom) recorded with $\mathrm{BaCl}_{2}(0.3 \mathrm{~mm})$ in the bath perfusion and a $\mathrm{CSMeSO}_{4}$ pipette solution. C, Kiss-induced current recorded using a $\mathrm{CMMSO}_{4}$ pipette solution in modified ACSF with $\mathrm{Na}^{+}$replaced by Li ${ }^{+}$. D, Kiss-induced current recorded using a $\mathrm{CsMeSO}_{4}$ pipette solution after pretreatment with NCX blocker KB-R7943 $(60 \mu \mathrm{M})$. E, Bar graph showing the amplitude of Kiss-induced current at $-125 \mathrm{mV}$ under different recording conditions. ${ }^{*} p<0.05 ;{ }^{* *} p<0.01$ vs normal ACSF; group $t$ test. Error bars indicate SEM.

$4 E, F)$. These results suggest that the excitation of kisspeptin on POMC neurons is not attributable to a modulation of presynaptic input.

\section{Kisspeptin directly evokes an inward current in POMC neurons}

To clarify the mechanism underlying this inward current, we compared the kisspeptin-evoked inward current under several conditions with modified ACSF bath solution or pipette solution. All recordings were done with TTX $(0.5 \mu \mathrm{M})$ in the bath. Using voltage-clamp recording at a holding potential of $-60 \mathrm{mV}$, kisspeptin $(1 \mu \mathrm{M})$ evoked an inward current in POMC neurons. The amplitude of this current was $31.4 \pm 7.3 \mathrm{pA}(n=8)$ (Fig. $5 A, H)$. In a nominal zero $\mathrm{Ca}^{2+} / 10 \mathrm{mM} \mathrm{Mg}^{2+}$ ACSF solution, kisspeptin evoked a smaller inward current (19.8 $\pm 5.4 \mathrm{pA})$, but the reduction was not significantly smaller than in control ACSF $(n=5)$ (Fig. $5 B, H)(p>0.05 ; n=13 ; t$ test). Next, BAPTA ( 10 $\mathrm{mM}$ ) was added to the pipette solution to buffer the intracellular $\mathrm{Ca}^{2+}$, and the kisspeptin evoked inward current was recorded. After the BAPTA diffused into the cell, kisspeptin $(1 \mu \mathrm{M})$ evoked only a very small inward current $(2.8 \pm$ $1.1 \mathrm{pA} ; n=6$ ) (Fig. 5C,H), significantly smaller than the current evoked by kisspeptin without BAPTA in the pipette ( $p<0.01 ; n=14 ; t$ test $)$. This suggests that the inward current is dependent on intracellular $\mathrm{Ca}^{2+}$, which is consistent with activation of both the $\mathrm{Na}-\mathrm{Ca}$ exchanger (NCX) and some nonselective cation currents (Ehara et al., 1989; Blair et al., 2009; Dong et al., 2009).

$\mathrm{Li}^{+}$can replace $\mathrm{Na}^{+}$in nonselective cation channels but is not able to replace $\mathrm{Na}^{+}$in most NCXs (Wu et al., 2004) (but see Palty et al., 2004). We replaced $80 \%$ of the $\mathrm{Na}^{+}$in the ACSF with $\mathrm{Li}^{+}$to see whether this replacement would change the kisspeptin-induced inward current. Under this condition, kisspeptin evoked an inward current with an amplitude of $13.7 \pm$ $4.6 \mathrm{pA}(n=6)$ (Fig. $5 D, H)$, which is smaller than the current obtained in normal ACSF $(p<0.05 ; n=14 ; t$ test $)$. Next, the NCX blocker, KB-R7943, was used (Wu et al., 2004; Huang and van den Pol, 2007; Parmentier et al., 2009). In the presence of KB-R7943 $(60 \mu \mathrm{M})$, the inward current evoked by kisspeptin $(1 \mu \mathrm{M})$ was decreased to $5.5 \pm 0.6 \mathrm{pA}(n=6)$ (Fig. $5 E, H)$, which was significantly smaller than the current evoked in the absence of this blocker $(p<0.01 ; n=14 ; t$ test $)$. Together, these results suggest that one mechanism underlying the inward current induced by kisspeptin is based on activation of the NCX current. Although the primary action of KB-R7943 is to block the NCX, it is also reported to have a partial side effect in attenuating nonselective cation currents (Kraft, 2007), and this may explain why KB-R7943 exerted a greater effect than $\mathrm{Li}^{+}$substitution for $\mathrm{Na}^{+}$. A newer benzyloxyphenyl NCX blocker SN-6, which is more selective to NCXs compared with KB-R7943 (Niu et al., 2007), was also used here. In the presence of SN-6 $(10 \mu \mathrm{M})$, kisspeptin $(1 \mu \mathrm{M})$ induced an attenuated inward current of $11.8 \pm 2.4 \mathrm{pA}(n=7)$, which is smaller than the current evoked in normal ACSF ( $p<0.05 ; n=15 ; t$ test) (Fig. $5 F, H)$, further supporting the involvement of the NCX in kisspeptin-induced inward current in POMC cells.

Next, the effect of SKF96365, a blocker of nonselective cation channels (Wang et al., 2007; Tsunematsu et al., 2008; Dong et al., 2009) was tested. In the presence of SKF96365 (10 $\mu \mathrm{M})$, kisspeptin $(1 \mu \mathrm{M})$ induced an inward current of $11.3 \pm 1.9 \mathrm{pA}(n=6)$, statistically smaller than the current evoked in normal ACSF ( $p<0.05 ; n=14$; $t$ test) (Fig. $5 G, H$ ), suggesting that the activation of nonselective cation channels may be another mechanism by which kisspeptin induced an inward current in POMC cells, similar to that reported in GnRH neurons (Zhang et al., 2008).

To address further the underlying mechanisms of kisspeptin action, we next used voltage ramps. In GnRH neurons, kisspeptin may act via the reduction of inward rectified potassium currents (Dumalska et al., 2008). The kisspeptin evoked current was in- 
vestigated using a ramp voltage protocol from -130 to $0 \mathrm{mV}$ at a holding potential of $-60 \mathrm{mV}$. With the perfusion of normal ACSF with TTX $(0.5 \mu \mathrm{M})$, AP5 $(50 \mu \mathrm{M})$, CNQX $(10 \mu \mathrm{M}), \mathrm{BIC}(30 \mu \mathrm{M})$, and $\mathrm{CdCl}_{2}$ $(200 \mu \mathrm{M})$, using a $\mathrm{KMeSO}_{4}$ pipette solution, the ramp voltage input from -130 to $0 \mathrm{mV}$ induced a current response as shown in Figure $6 A$. Kisspeptin $(1 \mu \mathrm{M})$ increased the current evoked by this ramp protocol. After subtracting the control from the current found after applying kisspeptin, a kisspeptin-evoked current was obtained (Fig. 6A). The average amplitude of the kisspeptin-induced current was $51.9 \pm 12.4 \mathrm{pA}$ at $-125 \mathrm{mV}(n=9)$ (Fig. 6E); this is greater than the $31 \mathrm{pA}$ current described above in voltage clamp because of the more hyperpolarized membrane potential at which the current was measured.

To attenuate a possible inward rectified potassium current component from the kisspeptin-induced current, $\mathrm{BaCl}_{2}$ $(300 \mu \mathrm{M})$ was added to the ACSF bath solution and $\mathrm{a} \mathrm{CsMeSO}_{4}$-based pipette solution was used. Using the same voltage ramp as used in the control test above, kisspeptin $(1 \mu \mathrm{M})$ also evoked a current that was very similar to the kisspeptininduced current obtained in the absence of $\mathrm{Ba}^{2+}$ and with a $\mathrm{K}^{+}$pipette solution (Fig. 6B). The amplitude of this current at $-125 \mathrm{mV}$ was $45.2 \pm 11.7 \mathrm{pA}(n=8)$ (Fig. 6E). Since the substitution of $\mathrm{Cs}^{+}$ for $\mathrm{K}^{+}$in the pipette and the addition of $\mathrm{Ba}^{2+}$ to the ACSF had no substantive effect on kisspeptin mediated currents, this suggests that attenuation of a potassium current may not play a major role in the excitatory effect of kisspeptin on POMC cells.

When lithium was substituted for sodium and a voltage ramp was used as above, the amplitude of this kisspeptin-evoked current at $-125 \mathrm{mV}$ was decreased to $15.2 \pm 9.4 \mathrm{pA}(n=6)$ (Fig. $6 C, E)(p<0.05$ vs normal ACSF; $t$ test $)$, consistent with activation of the NCX as found with the voltage-clamp experiment above. In a second experiment also based on voltage ramp, after pretreatment with KB-R7943 $(60 \mu \mathrm{M})$, the kisspeptin-induced current was decreased to $11.8 \pm 5.9 \mathrm{pA}(n=7)($ Fig. $6 D, E)(p<$ 0.01 vs normal ACSF; $t$ test). These ramp results further support the view that the kisspeptin-evoked current may be mediated in part by a mechanism depending on the activation of the NCX.

\section{DHPG excites POMC neurons}

In septal GnRH neurons, none of the cells that responded to kisspeptin also responded to the group I metabotropic glutamate receptor agonist DHPG (Dumalska et al., 2008). Other septal GnRH cells that did respond to DHPG did not respond to kisspeptin. We therefore tested whether the same was true of POMC neurons. In striking contrast to GnRH neurons, all POMC cells tested were excited by DHPG (Fig. 7A,B). A $10 \mathrm{~s}$ application of DHPG $(10-50 \mu \mathrm{M})$ depolarized the POMC cells by $6.1 \pm 1.0 \mathrm{mV}$ from the starting membrane potential of $-57.2 \pm$
$1.6 \mathrm{mV}(p<0.01 ; n=8 ; t$ test $)$. In five cells excited by DHPG (depolarization, $7.2 \pm 1.1 \mathrm{mV} ; p<0.01 ; t$ test), we also applied kisspeptin $(1 \mu \mathrm{M})$ after the cell recovered from DHPG excitation and found that all five cells also responded to kisspeptin (depolarization, $5.8 \pm 0.7 \mathrm{mV} ; p<0.01 ; t$ test) (Fig. $7 A-D$ ). These results suggest that, unlike $\mathrm{GnRH}$ neurons, individual POMC cells in the arcuate nucleus are excited by both group I metabotropic glutamate receptor agonist DHPG and by kisspeptin.

\section{GnIH and RFRP-3 inhibit POMC neurons}

$\mathrm{GnIH}$-immunoreactive axons are found throughout the arcuate nucleus (see Fig. 9D). In studies on POMC-GFP transgenic mice, we found red $\mathrm{GnIH}$-immunoreactive terminals apposed to green POMC cells ( $n=4$ mice). GnIH inhibits GnRH neurons (Tsutsui et al., 2000; Wu et al., 2009), but electrophysiological effects on other types of neurons have not been reported. We tested the effect of GnIH on POMC cells. GnIH consistently inhibited POMC cells. GnIH in a range of concentrations from $10 \mathrm{~nm}$ to 1 $\mu \mathrm{M}$ inhibited POMC cells dose-dependently, with GnIH (1 $\mu \mathrm{M})$ decreasing the spike frequency by $89.9 \pm 1.8 \%(p<0.01 ; n=6$; ANOVA) and hyperpolarizing the membrane by $10.5 \pm 2.6 \mathrm{mV}$ from the starting membrane potential of $57.1 \pm 2.2 \mathrm{mV}(p<$ $0.01 ; n=6$; ANOVA) (Fig. $8 A, B, D, E)$. The mammalian analog 

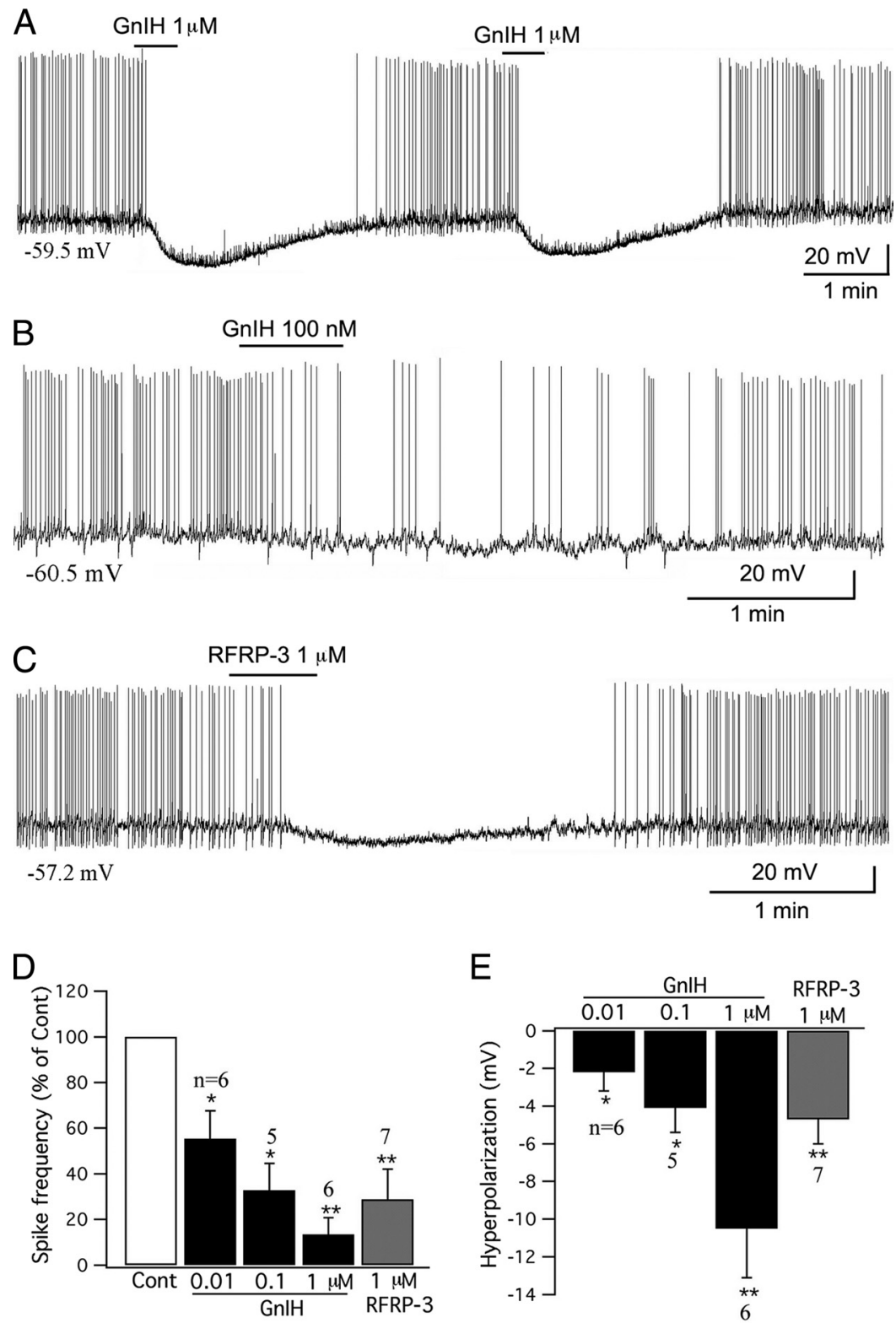

\section{F $\quad$ TTX+AP5+CNQX+BIC}

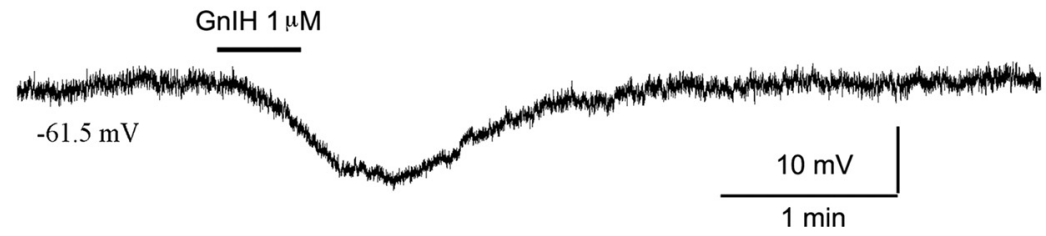

Figure 8. GnIH inhibits POMC cells in arcuate nucleus. $A$, A typical trace showing that GnIH $(1 \mu \mathrm{m})$ inhibited the firing and hyperpolarized the membrane potential of a POMC cell. The effect was repeatable with four successive applications of GnIH; only the first two applications are shown here. $B$, GnIH (100 nM) inhibited a POMC cell. C, The mammalian analog of GnIH, RFRP-3 $(1 \mu \mathrm{M})$ depressed a POMC cell. $\boldsymbol{D}$, Bar graph showing the dose-dependent effects of $\mathrm{GnIH}(0.01-1 \mu \mathrm{M})$ and RFRP-3 $(1 \mu \mathrm{M})$ on the spike frequency of POMC cells (control, 100\%; ${ }^{*} p<0.05,{ }^{* *} p<0.01$ vs Cont; ANOVA). $E$, Bar graph showing the dose-dependent hyperpolarization that GnIH (0.01-1 $\mu \mathrm{M})$ and RFRP-3 $(1 \mu \mathrm{M})$ had on POMC cells $\left({ }^{*} p<0.05,{ }^{* *} p<0.01\right.$ vs Cont; ANOVA). Error bars indicate SEM. $F$, Trace showing that GnIH (1 $\mu \mathrm{m})$ hyperpolarized a POMC cell in the presence of TTX $(0.5 \mu \mathrm{M}), \operatorname{AP5}(50 \mu \mathrm{M})$, CNQX $(10 \mu \mathrm{M})$, and BIC $(30 \mu \mathrm{m})$ in bath solution, indicating a direct effect.

of GnIH, RFRP-3 (1 $\mu \mathrm{M})$, also depressed POMC cells, with a $71.2 \pm 13.5 \%$ reduction in spike frequency $(p<0.01 ; n=7$; ANOVA) and $4.7 \pm 1.3 \mathrm{mV}$ hyperpolarization from the starting membrane potential of $-59.0 \pm 1.7 \mathrm{mV}(p<0.01 ; n=7$;
ANOVA) (Fig. 8C-E). In the presence of TTX $(0.5 \mu \mathrm{M})$, AP5 $(50 \mu \mathrm{M})$, CNQX (10 $\mu \mathrm{M})$, and BIC $(30 \mu \mathrm{M})$ in the bath solution, GnIH $(1 \mu \mathrm{M})$ hyperpolarized POMC cells by $5.0 \pm 2.0 \mathrm{mV}$ from the starting membrane potential of $-62.4 \pm 3.0 \mathrm{mV}$ $(p<0.05 ; n=6$; ANOVA) (Fig. $8 F)$, suggesting that $\mathrm{GnIH}$ inhibits POMC cells via a direct postsynaptic effect.

To study the effect of GnIH on input resistance, the current-voltage relationship before and during application of $\mathrm{GnIH}$ (1 $\mu \mathrm{M})$ was obtained by injecting a series of square-wave currents from -80 to $0 \mathrm{pA}$. The input resistance was calculated from the linear part of the current-voltage relationship curve. GnIH ( $1 \mu \mathrm{M})$ decreased the input resistance by $23.5 \pm 6.6 \%$ (control, $1210 \pm 158 \mathrm{M} \Omega ; \mathrm{GnIH}, 954 \pm 197 \mathrm{M} \Omega ; p<$ $0.01 ; n=5$; $t$ test). These data suggest that $\mathrm{GnIH}$ inhibits POMC neurons by opening ion channels in the cell membrane.

The inhibitory action of $\mathrm{GnIH}$ on GnRH neurons involves activation of potassium channels (Wu et al., 2009). To test whether GnIH may inhibit POMC neurons via the same mechanism, in the presence of TTX $(0.5 \mu \mathrm{M})$, AP5 $(50 \mu \mathrm{M})$, CNQX $(10 \mu \mathrm{M}), \mathrm{BIC}(30 \mu \mathrm{M})$, and $\mathrm{CdCl}_{2}$ $(200 \mu \mathrm{M})$ in the ACSF, a voltage ramp from -120 to $-20 \mathrm{mV}$ was delivered to the cells under voltage-clamp recording. This generated a current with a mean reversal potential of $-91.7 \pm 5.9 \mathrm{mV}(n=$ 6 ), which is consistent with opening potassium channels.

\section{GnIH and NPY attenuate kisspeptin excitation of POMC neurons}

Above, we show that GnIH inhibits POMC neurons. To determine whether GnIH might reduce the long-lasting excitation elicited by kisspeptin, in six POMC cells, we applied kisspeptin $(1 \mu \mathrm{M})$ first, which excited the POMC cells (spike frequency increased to $339 \pm 68 \%$ of the control; $p<0.05$; and membrane potential was depolarized by $6.4 \pm 1.7 \mathrm{mV} ; p<0.05$; ANOVA with Bonferroni's post hoc test). After the activity of the kisspeptin-excited cells stabilized, GnIH $(1 \mu \mathrm{M})$ was applied for $1 \mathrm{~min}$ in the place of kisspeptin. GnIH greatly reduced the longlasting kisspeptin excitation (spike frequency was reduced to $54.4 \pm 20.9 \%$ of the control, and $19.8 \pm 8.6 \%$ of the kisspeptin-mediated spike frequency; $p<$ 0.01; ANOVA and hyperpolarized the membrane (by $0.2 \pm 2.6 \mathrm{mV}$ compared with control, and $6.6 \pm 2.0 \mathrm{mV}$ compared with kisspeptin-mediated depolarization; $p<0.01$; ANOVA with Bonferroni's post hoc test) (Fig. 9A-C).

In another six POMC cells, kisspeptin (10 nM) was applied continuously through the flow pipette to excite the cells. After obtaining 
a relatively stable level of excitation (spike frequency increased to $380 \pm 64 \%$ of the control), GnIH (1 $\mu \mathrm{M})$ together with kisspeptin (10 nM) was applied to these cells. The excitation of kisspeptin in these cells was significantly reversed by the presence of $\mathrm{GnIH}$ (the spike frequency decreased to $19 \pm 8 \%$ compared with the level without GnIH; $p<0.01$; ANOVA). Interestingly, this spike depression completely recovered after washing out $\mathrm{GnIH}$ (spike frequency was $440 \pm 126 \%$ vs control) (Fig. $9 E-G$ ). These results again suggest that $\mathrm{GnIH}$ can transiently block kisspeptin actions, but in the absence of GnIH, kisspeptinmediated excitation recovers. As kisspeptin and $\mathrm{GnIH}$ actions are mediated by different G-protein mechanisms, the transient GnIH-mediated inhibition of kisspeptin excitation is most likely based on the negative shift in membrane potential away from the spike threshold as $\mathrm{K}^{+}$ channels open, and the reduction in input resistance mediated by $\mathrm{GnIH}$.

NPY is found in axons that terminate on cells expressing POMC immunoreactivity (Cowley et al., 2001; Menyhért et al., 2006) and, similarly, terminate near POMC cells expressing GFP, as shown in Figure $9 \mathrm{H}$. We therefore examined the effect of NPY on the kisspeptin-mediated excitation. In nine POMC cells, we first applied kisspeptin $(1 \mu \mathrm{M})$, which increased action potential frequency (spike frequency was increased to $299 \pm 43 \%$ of the control; $p<0.05$; and membrane potential was depolarized by $6.4 \pm 1.6 \mathrm{mV}$; $p<0.05$; ANOVA). NPY $(1 \mu \mathrm{M})$ was then applied to these excited cells for $1 \mathrm{~min}$. Similar to GnIH, NPY attenuated the kisspeptin-induced excitation (spike frequency was reduced to $19.6 \pm 11.0 \%$ of the control, and $11.2 \pm 8.5 \%$ of kisspeptinmediated spike frequency; $p<0.01$ vs kisspeptin; ANOVA with Bonferroni's post hoc test) and hyperpolarized the membrane (by $3.7 \pm 2.3 \mathrm{mV}$ compared with control, and $10.1 \pm 2.1 \mathrm{mV}$ compared with kisspeptin; $p<0.01$ vs kisspeptin; ANOVA with Bonferroni's post hoc test) of these cells (Fig. $9 I-K)$. Similar to our findings with $\mathrm{GnIH}$, NPY has previously been reported to inhibit POMC cells by a mechanism based on activation of outward $\mathrm{K}^{+}$current (Roseberry et al., 2004; Acuna-Goycolea and van den Pol, 2005).

\section{Kisspeptin inhibits NPY cells in the arcuate nucleus by enhancing inhibitory synaptic activity}

A current model of the central control of food intake suggests that the NPY neurons in the arcuate nucleus oppose the

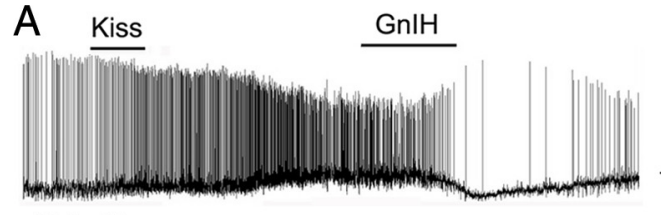
$\frac{20 \mathrm{mV}}{1 \mathrm{~min}}$
$-57.7 \mathrm{mV}$

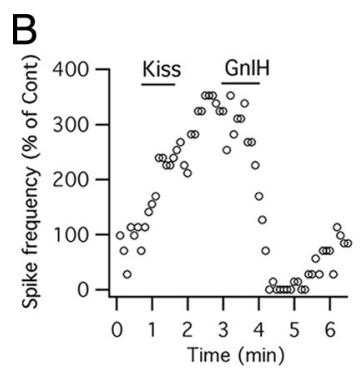

E Kiss GnIH

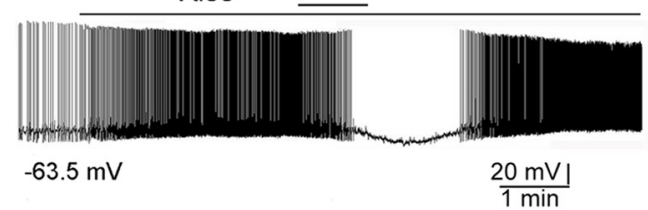

$\mathrm{F}$
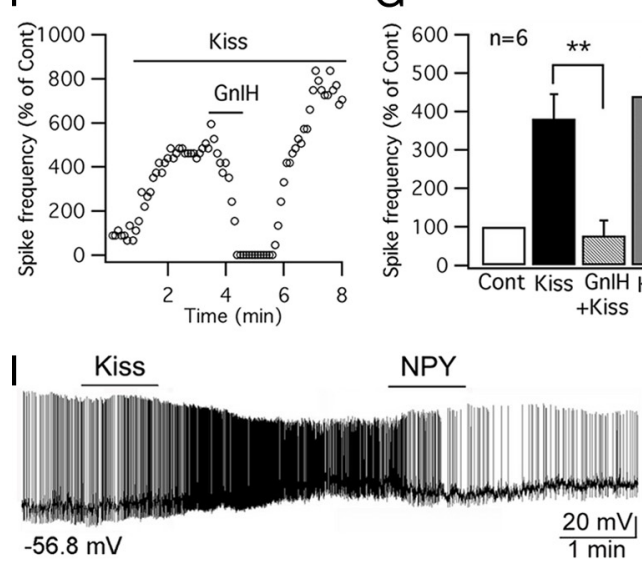

$\mathrm{J}$
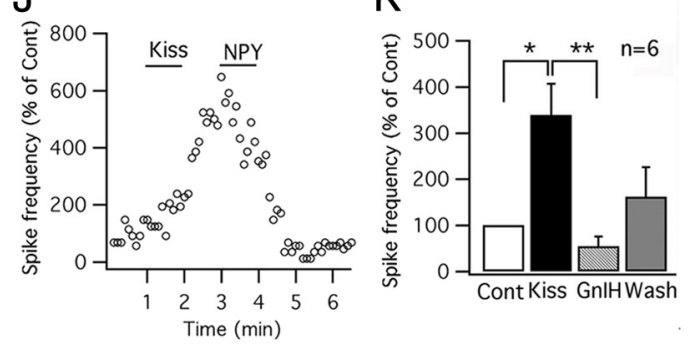

$\mathrm{K}$

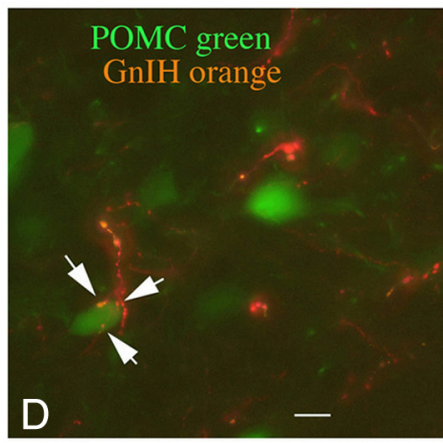

G
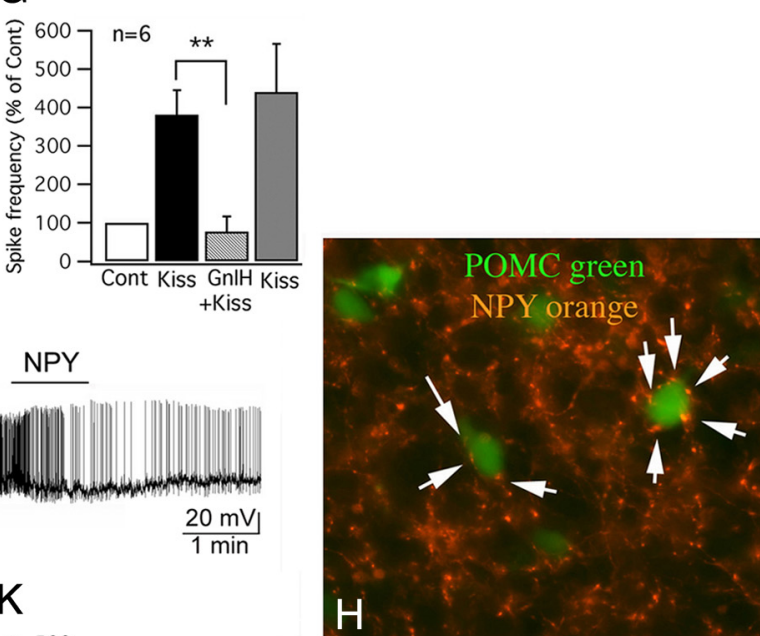

Figure 9. GnIH and NPY inhibit the effect of kisspeptin on POMC cells. A, Trace showing that a POMC cell was excited by kisspeptin $(1 \mu \mathrm{M})$, and the effect of kisspeptin was reduced by $\mathrm{GnIH}(1 \mu \mathrm{M})$, and instead the cell was hyperpolarized after GnIH (1 $\mu \mathrm{M}) . \boldsymbol{B}$, Time course curve of the effect of kisspeptin and $\mathrm{GnlH}$ on spike frequency of the cell shown in trace in $\boldsymbol{A}$. $\boldsymbol{C}$, Bar graph showing the spike frequency changes in POMC cells with application of kisspeptin and GnlH (control, 100\%; * $p<0.05$ vs Cont, ${ }^{* *} p<0.01$ vs kisspeptin; $n=6$; ANOVA). D, In this micrograph, POMC cells express GFP and are green, and axons containing GnIH are immunostained orange. The arrows indicate $\mathrm{GnIH-immunoreactive} \mathrm{axons} \mathrm{and} \mathrm{boutons} \mathrm{terminating} \mathrm{near} \mathrm{or} \mathrm{on} \mathrm{POMC} \mathrm{neurons.}$ Scale bar, $12 \mu \mathrm{m} . \boldsymbol{E}, \mathrm{GnIH}$ applied during kisspeptin application blocked the spike increase. On GnlH washout, the kisspeptinincreased spike frequency recovered. $\boldsymbol{F}$, Time course of an example cell, similar to that shown in $\boldsymbol{E}$. $\boldsymbol{G}$, Bar graphs showing mean effect of kisspeptin, kisspeptin plus $\mathrm{GnIH}$, and recovery in kisspeptin after $\mathrm{GnIH}$ washout ( ${ }^{* *} p<0.01$ vs kisspeptin; $n=6$; ANOVA). $\boldsymbol{H}$, Orange NPY-immunoreactive axons and boutons (arrows) terminate near or on green POMC neurons. Scale bar, $12 \mu \mathrm{m}$. $\boldsymbol{I}$, Trace showing that kisspeptin ( $1 \mu \mathrm{M})$ excited a POMC cell, and the excitation was reduced by NPY (1 $\mu \mathrm{M})$. $J$, Time course of the effect of kisspeptin and NPY on spike frequency of the cell in trace I. $\boldsymbol{K}$, Bar graph showing the spike frequency changes of POMC cells after applying kisspeptin and NPY (control, $100 \%$; ${ }^{*} p<0.05$ vs Cont, ${ }^{* *} p<0.01$ vs kisspeptin; $n=6$; ANOVA). Error bars indicate SEM. The membrane potential values under the traces in $\boldsymbol{A}, \boldsymbol{E}$, and $\boldsymbol{I}$ indicate the membrane potential before applying kisspeptin. 
A

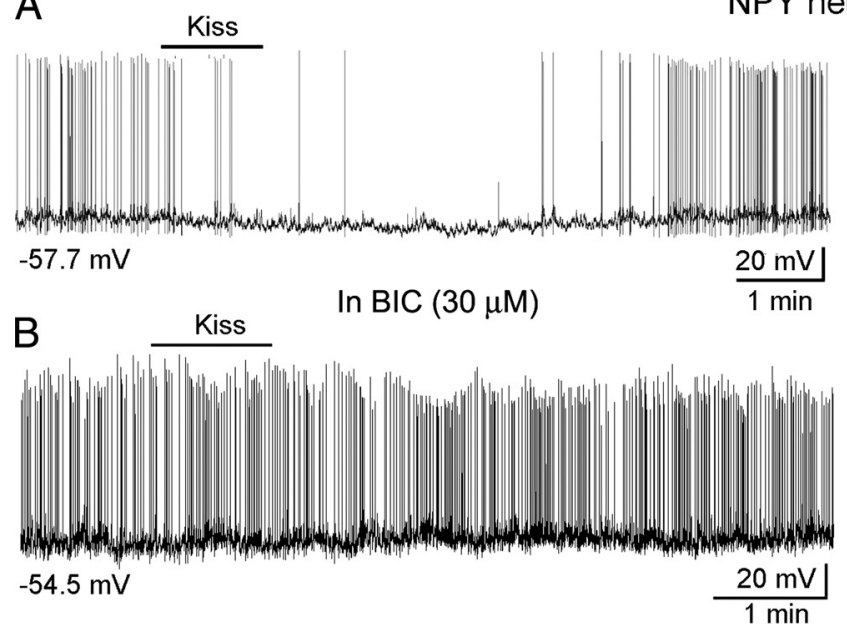

E

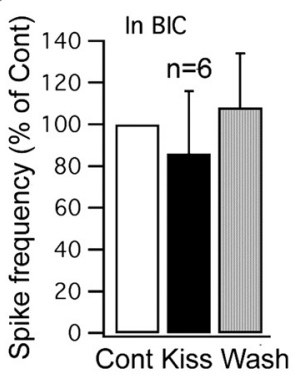

$F \ln T T X+A P 5+C N Q X+B I C$

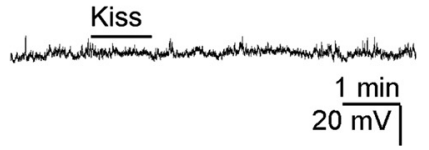

G

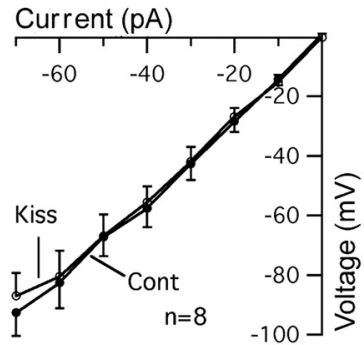

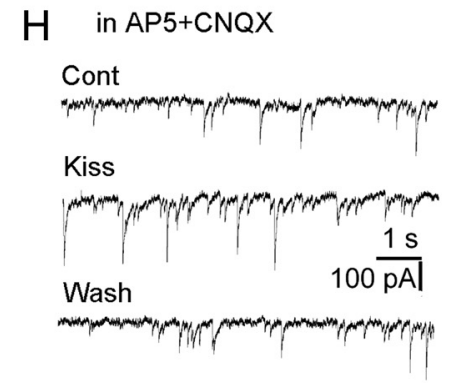

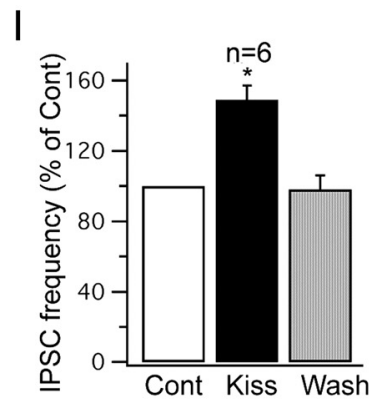

J in AP5+CNQX+TTX

Cont

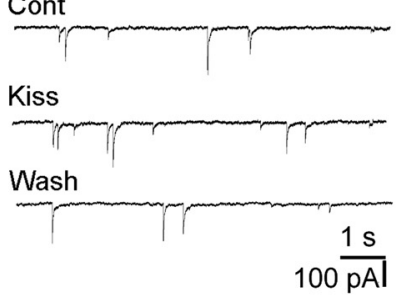

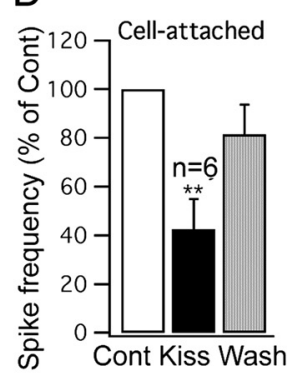

C

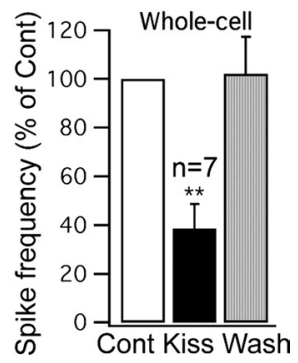

$\mathrm{D}$

anorexigenic actions of the POMC cells (Cowley et al., 2001; Heisler et al., 2003; Hill et al., 2008). The effect of kisspeptin on these NPY cells in the arcuate nucleus was investigated using a transgenic mouse expressing bright Renilla GFP selectively in NPY neurons (van den Pol et al., 2009). In contrast to the excitation found in POMC cells, kisspeptin showed consistent inhibitory effects on NPY cells (Fig. $10 A, C, D)$. Inhibitory actions of kisspeptin have not been previously found. With whole-cell recording, kisspeptin ( $1 \mu \mathrm{M})$ for $1 \mathrm{~min}$ reduced the spike frequency by $61 \pm 10 \%$ of control $(p<0.01 ; n=7$; ANOVA) (Fig. 10C), and the membrane potential was hyperpolarized by $5.0 \pm 1.9$ $\mathrm{mV}$ from a starting membrane potential of $-57.7 \mathrm{mV}(p<0.01 ; n=7$; ANOVA $)$. Consistent with the whole-cell recording, when we used cell-attached recording to eliminate any possibility of the pipette altering the intracellular milieu, kisspeptin $(1 \mu \mathrm{M})$ also decreased the action current of NPY cells by $58 \pm 12 \%(p<0.01 ; n=$ 6; ANOVA) (Fig. 10D).

The inhibition of kisspeptin on NPY cells was significantly attenuated by adding BIC $(30 \mu \mathrm{M})$ to the bath. In the presence of BIC, kisspeptin $(1 \mu \mathrm{M})$ did not decrease the spike frequency of NPY cells significantly $(14 \pm 30 \%$ decrease; $p>$ $0.05 ; n=6$; ANOVA) (Fig. $10 B, E$ ), suggesting that the inhibition of kisspeptin on NPY neurons is primarily dependent on GABAergic input to NPY cells. Furthermore, we tested whether kisspeptin acts directly on NPY cells. In the presence of TTX $(0.5 \mu \mathrm{M}), \operatorname{AP5}(50 \mu \mathrm{M}), \mathrm{CNQX}$ (10 $\mu \mathrm{M})$, and BIC $(30 \mu \mathrm{M})$ to block synaptic actions, kisspeptin did not significantly change the membrane potential $(-1.2 \pm$ $0.6 \mathrm{mV} ; p>0.05 ; n=9$; ANOVA) (Fig. $10 F)$. Similarly, the input resistance was not changed significantly under the same conditions (control, $1234 \pm 93 \mathrm{M} \Omega$; kisspeptin, $1282 \pm 102 \mathrm{M} \Omega ; p>0.05 ; n=8$; $t$ test) (Fig. $10 G)$. These results suggest that the inhibition of kisspeptin on NPY cells is not attributable to a direct effect on NPY cells.

Next, we investigated the effect of kisspeptin on inhibitory synaptic transmission. In the presence of AP5 and CNQX in the bath, IPSCs were recorded

$\leftarrow$

recorded with a $\mathrm{KCl}$ pipette solution in the presence of $A P 5$ and CNQX in the bath. I, Bar graph showing the increase of IPSC frequency by kisspeptin on NPY cells. J, mIPSC traces before and during application of kisspeptin $(1 \mu \mathrm{M})$ and after washout. $\boldsymbol{K}$, The increase by kisspeptin of mIPSC frequency on NPY cells. $L$, Kisspeptin did not change the amplitude of mIPSCS on NPY cells. ${ }^{*} p<0.05 ;{ }^{* *} p<0.01$; ANOVA. Error bars indicate SEM.

firing and hyperpolarizes an NPY cell with whole-cell recording. $\boldsymbol{B}$, Trace showing that kisspeptin (1 $\mu \mathrm{M})$ failed to inhibit the firing
firing of an NPY cell in the presence of BIC (30 $\mu \mathrm{m})$ in the bath. Starting membrane potential shown under the trace. $C, D$, Bar graphs showing the reversible decrease of spike frequency of NPY cells by kisspeptin $(1 \mu \mathrm{m})$ with whole-cell recording $(\boldsymbol{C})$ and cellattached recording (D).E, Kisspeptin failed to decrease the spike frequency of NPY cells significantly in the presence of BIC ( $30 \mu \mathrm{M})$. $\boldsymbol{F}$, In the presence of TTX $(0.5 \mu \mathrm{m}), \operatorname{AP5}(50 \mu \mathrm{m})$, CNQX $(10 \mu \mathrm{M})$, and BIC $(30 \mu \mathrm{M})$, kisspeptin did not change the membrane potential of a NPY cell. $\mathbf{G}$, The current-voltage relationship of NPY cell with current injection from -70 to $0 \mathrm{pA}$ before and after application of kisspeptin (1 $\mu \mathrm{M})$. $\boldsymbol{H}$, IPSCs before and during application of kisspeptin (1 $\mu \mathrm{M})$ and after washout. IPSCS were 
with a $\mathrm{KCl}$ pipette solution. Kisspeptin (1 $\mu \mathrm{M})$ increased the frequency of IPSCs by $45 \pm 8 \%(p<0.05 ; n=6$; ANOVA) (Fig. $10 H, I)$. In TTX along with AP5 and CNQX in the bath, miniature IPSCs (mIPSCs) were recorded, and kisspeptin $(1 \mu \mathrm{M})$ was found to increase the frequency of mIPSCs by $35 \pm 9 \%(p<0.01$; $n=6$; ANOVA) without changing the amplitude of mIPSCs (control amplitude, $63 \pm 8$ pA; kisspeptin, $59 \pm 6 \mathrm{pA} ; p>$ $0.05 ; n=6$; ANOVA) (Fig. $10 \mathrm{~J}-L$ ). The increase in frequency without a change in amplitude suggests a presynaptic action of kisspeptin on GABA axons to enhance transmitter release.

\section{Discussion}

Kisspeptin is a recently identified neuropeptide critical for the induction of puberty and maintenance of fertility. In the absence of the peptide or its receptor, humans and rodents do not reach puberty and remain sterile. The physiological actions of kisspeptin have so far primarily been studied in $\mathrm{GnRH}$ neurons. Because reproduction is provisionally dependent on the availability of sufficient energy resources, we examined the actions of kisspeptin on neurons of the arcuate nucleus that sense and regulate food intake and energy homeostasis. With immunocytochemistry, we found many kisspeptin-immunoreactive axonal boutons terminating on or near POMC neurons. With whole-cell recording, we found a potent, dose-dependent excitation of kisspeptin on POMC neurons. In contrast, kisspeptin inhibited NPY cells by a presynaptic mechanism. Both $\mathrm{GnIH}$ and the orexigenic peptide NPY inhibited POMC neurons and also attenuated kisspeptin excitation; direct electrophysiological actions of $\mathrm{GnIH}$ had previously only been found in GnRH neurons (Ducret et al., 2009; Wu et al., 2009).

\section{Mechanism of kisspetin action}

Kisspeptin consistently depolarized the membrane potential, increased the firing rate, and reduced input resistance of POMC neurons, and the depolarizing effect persisted in the presence of TTX. The mechanism of the excitation of kisspeptin on POMC cells appears to be based primarily on the activation of a NCX, as suggested by the following observations: The inward current evoked by kisspeptin was decreased by replacement of the $\mathrm{Na}^{+}$in the ACSF by $\mathrm{Li}^{+}$(Wu et al., 2004), by the intracellular calcium chelator BAPTA, and by the NCX blocker KB-R7943 (Wu et al., 2004; Huang and van den Pol, 2007). As NCX blockers may not fully block, and may have additional actions, we showed that another more selective NCX blocker, SN-6 (Niu et al., 2007), also attenuates kisspeptin actions, further supporting a mechanism based on the NCX. We cannot exclude a second mechanism based on activation of a nonselective cation current, consistent with the partial attenuation by SKF96365, a blocker of nonselective cation channels (Wang et al., 2007; Tsunematsu et al., 2008; Dong et al., 2009), and the modest decrease in input resistance. Furthermore, intracellular BAPTA, which attenuates the NCX, may also attenuate some nonselective cation currents. Thus, in
POMC neurons, kisspeptin appears to activate the NCX and may also activate nonselective cation currents, whereas in $\mathrm{GnRH}$ neurons it activates a nonselective cation current (Liu et al., 2008; Zhang et al., 2008) and attenuates a $\mathrm{Ba}^{2+}$-sensitive potassium channel (Dumalska et al., 2008; Liu et al., 2008). In POMC neurons, substitution of $\mathrm{Cs}^{+}$for $\mathrm{K}^{+}$, and addition of $\mathrm{Ba}^{2+}$ had little effect on kisspeptin-mediated excitation, suggesting that attenuation of $\mathrm{K}^{+}$conductance was not a primary mechanism. Another difference between GnRH and POMC neurons is that single POMC cells were excited by both kisspeptin and the metabotropic glutamate agonist DHPG, whereas single GnRH cells responded only to one or the other, not both (Dumalska et al., 2008). These data indicate that POMC cells can be serially excited by both glutamate via a G-protein cascade, and by G-proteincoupled kisspeptin actions. We did not find a significant effect of kisspeptin on either EPSCs or IPSCs in POMC cells.

The inhibition of kisspeptin on NPY cells is mediated by an indirect mechanism, presynaptic activation of GABAergic neurons. Since we found that kisspeptin excites POMC neurons, which also may contain GABA (Hentges et al., 2004), the increase in GABAergic synaptic tone in the NPY neurons hypothetically may arise from kisspeptin activation of POMC neurons (Fig. 11). Although the projection of NPY cells to POMC neurons is substantial (Cowley et al., 2001), models of arcuate neuron interaction include a POMC projection to NPY neurons (Barsh and Schwartz, 2002; Seeley, 2004), supported by the detection of POMC-immunoreactive axons terminating on NPY cells in some species (Menyhért et al., 2006), and the expression of melanocortin receptors by NPY cells (Mounien et al., 2005). Alternately, kisspeptin may excite other non-POMC GABA neurons that 
project to the NPY cells. Parallel to its actions on NPY cells, kisspeptin also increases synaptic activity in GnRH neurons (Pielecka-Fortuna and Moenter, 2010) and in hippocampal dentate granule neurons (Arai et al., 2005). Similar to kisspeptin actions in the arcuate nucleus, the metabolic hormone that signals fat content, leptin, directly depolarizes POMC neurons while hyperpolarizing NPY neurons (Cowley et al., 2001); in parallel, leptin and insulin increase POMC gene expression while inhibiting NPY gene expression (Schwartz et al., 1992; Elias et al., 1999; Benoit et al., 2002).

GnIH/RFRP-3-mediated inhibition of POMC cells appears to be based on opening $\mathrm{K}^{+}$channels, as suggested by the direct hyperpolarization in the presence of TTX, the reduction in input resistance, and the reversal potential of $-91 \mathrm{mV}$.

Functional relevance to energy homeostasis and reproduction As noted previously, the POMC neuron plays a key role in reducing energy intake, whereas the NPY/AgRP cell plays an important orexigenic role in energy homeostasis. Thus, the strong direct excitation of POMC cells by kisspeptin, coupled with the indirect inhibition of NPY neurons, suggests that, under some conditions, kisspeptin may serve to modulate energy homeostasis. Our results showing the opposing actions of kisspeptin on anorexigenic POMC and orexigenic NPY cells further support the view that kisspeptin may modulate, in opposite directions, both arms of the arcuate nucleus energy homeostasis circuitry. That leptin increases kisspeptin gene expression (Smith et al., 2006; Hill et al., 2008) further supports the view that kisspeptin neurons may play a modulatory role in energy homeostasis. This perspective becomes even more interesting with our data showing that $\mathrm{GnIH}$ (and NPY) exerts a direct inhibitory action on POMC cells and blocks kisspeptin excitation. Inhibition of an anorexigenic neuron such as the POMC cell would be predicted to enhance food intake, consistent with the orexigenic actions of GnIH (Tachibana et al., 2005, 2008; Johnson et al., 2007). Thus, the converging points of evidence from our electrophysiological analyses of the responses of POMC and NPY cells to kisspeptin and GnIH are consistent with the view that GnIH may play its orexigenic role within established arcuate nucleus circuitry. Speculatively, kisspeptin may act to reverse the orexigenic actions of $\mathrm{GnIH}$, and in the absence of $\mathrm{GnIH}$, kisspeptin exerts no feeding phenotype, consistent with evidence showing kisspeptin alone evokes little feeding phenotype (Thompson et al., 2004; Castellano et al., 2005).

Although a direct effect of kisspeptin and GnIH on GnRH cells would be stronger, we cannot rule out the possibility of indirect modulation of reproduction through the POMC and NPY neurons. GnRH neurons receive an innervation from both POMC and NPY neurons (Leranth et al., 1988; Chen et al., 1989; Tsuruo et al., 1990; Rondini et al., 2004; Ward et al., 2009). POMC-derived peptides and their receptors can enhance the activity of GnRH neurons (Watanobe et al., 1999; Matsuyama et al., 2005). Recent evidence supports the view that the arcuate nucleus may play a key role in luteinizing hormone and GnRH pulse generation (Ohkura et al., 2009). Importantly, kisspeptin actions in the arcuate nucleus are essential to this pulse generation ( $\mathrm{Li}$ et al., 2009). Activation of central melanocortin receptors stimulates GnRH pulse generator activity (Matsuyama et al., 2005) and gonadotropin secretion in humans (Reid et al., 1981) and rats (Watanobe et al., 1999). Thus, in addition to direct excitation on $\mathrm{GnRH}$ neurons, kisspeptin may regulate $\mathrm{GnRH}$ neuronal activity by exciting POMC neurons of the arcuate nucleus. NPY also participates in the control of $\mathrm{GnRH} /$ luteinizing hormone secretion in rats (Kalra et al., 1995). NPY neurons contact GnRH neurons (Li et al., 1999) and provide an inhibitory tone to GnRH neurons (Xu et al., 2000). NPY suppresses the neuronal activity of the GnRH pulse generator (Ichimaru et al., 2001). Thus, the actions of kisspeptin on POMC and NPY cells we describe here may play a role in $\mathrm{GnRH}$ pulse generation, potentially related to energy state. An overview of the cellular interactions that we discuss is shown schematically in Figure 11.

Recent studies suggest that the hypothalamic kisspeptin system may participate in transmitting metabolic information into brain regions controlling the reproductive axis (Tena-Sempere, 2006; Hill et al., 2008; Roa et al., 2008; Castellano et al., 2009). Fasting reduces hypothalamic kisspeptin mRNA expression (Castellano et al., 2005; Luque et al., 2007; Brown et al., 2008), which precedes the fasting-induced decline of GnRH. Hypothalamic kisspeptin mRNA levels decrease in diabetic rats, concomitant with reduced gonadotropin secretion, and kisspeptin treatment rescues reproductive function (Castellano et al., 2006). The kisspeptin innervation and modulation of POMC and NPY neurons may serve to link the reproductive axis with metabolic state. NPY neurons are active in conditions of negative energy balance. Increased NPY release may then stimulate feeding while inhibiting release of $\mathrm{GnRH}$ and pituitary-gonadal axis activity. $\alpha$-MSH, released from POMC neurons, is considered an anorexigenic peptide, which can increase energy expenditure and inhibit feeding via MC3/4 receptors (Brown et al., 1998; Cowley et al., 1999). POMC mRNA is reduced by fasting (Bergendahl et al., 1992). Since $\alpha-\mathrm{MSH}$ activates the GnRH system, during conditions of low energy, the decreased POMC activity may also contribute to the suppression of GnRH release. POMC neurons send axon collaterals to the median eminence (Acuna-Goycolea and van den Pol, 2009), allowing kisspeptin to potentially modulate the release of POMC-related peptides and thereby modulate pituitary secretions, possibly including luteinizing hormone.

In summary, our data suggest that, similar to their opposing effects on $\mathrm{GnRH}$ neurons, kisspeptin excites and GnIH inhibits and blocks the kisspeptin-mediated excitation of POMC neurons, with functional ramifications for both energy homeostasis and reproduction potential.

\section{References}

Acuna-Goycolea C, van den Pol AN (2005) Peptide YY(3-36) inhibits both anorexigenic proopiomelanocortin and orexigenic neuropeptide $\mathrm{Y}$ neurons: implications for hypothalamic regulation of energy homeostasis. J Neurosci 25:10510-10519.

Acuna-Goycolea C, van den Pol AN (2009) Neuroendocrine proopiomelanocortin neurons are excited by hypocretin/orexin. J Neurosci 29:1503-1513.

Arai AC, Xia YF, Suzuki E, Kessler M, Civelli O, Nothacker HP (2005) Cancer metastasis-suppressing peptide metastin upregulates excitatory synaptic transmission in hippocampal dentate granule cells. J Neurophysiol 94:3648-3652.

Barsh GS, Schwartz MW (2002) Genetic approaches to studying energy balance: perception and integration. Nat Rev Genet 3:589-600.

Batterham RL, Cowley MA, Small CJ, Herzog H, Cohen MA, Dakin CL, Wren AM, Brynes AE, Low MJ, Ghatei MA, Cone RD, Bloom SR (2002) Gut hormone PYY(3-36) physiologically inhibits food intake. Nature 418:650-654.

Bekkers JM, Stevens CF (1995) Quantal analysis of EPSCs recorded from small numbers of synapses in hippocampal cultures. J Neurophysiol 73:1145-1156.

Benoit SC, Air EL, Coolen LM, Strauss R, Jackman A, Clegg DJ, Seeley RJ, Woods SC (2002) The catabolic action of insulin in the brain is mediated by melanocortins. J Neurosci 22:9048-9052.

Bergendahl M, Wiemann JN, Clifton DK, Huhtaniemi I, Steiner RA (1992) Short-term starvation decreases POMC mRNA but does not alter GnRH mRNA in the brain of adult male rats. Neuroendocrinology 56:913-920. 
Blair NT, Kaczmarek JS, Clapham DE (2009) Intracellular calcium strongly potentiates agonist-activated TRPC5 channels. J Gen Physiol 133:525-546.

Boston BA (2001) Pro-opiomelanocortin and weight regulation: from mice to men. Pediatr Endocrinol Metab 14:1409-1416.

Brailoiu GC, Dun SL, Ohsawa M, Yin D, Yang J, Chang JK, Brailoiu E, Dun NJ (2005) KiSS-1 expression and metastin-like immunoreactivity in the rat brain. J Comp Neurol 481:314-329.

Brown KS, Gentry RM, Rowland NE (1998) Central injection in rats of alpha-melanocyte-stimulating hormone analog: effects on food intake and brain Fos. Regul Pept 78:89-94.

Brown RE, Imran SA, Ur E, Wilkinson M (2008) KiSS-1 mRNA in adipose tissue is regulated by sex hormones and food intake. Mol Cell Endocrinol 281:64-72.

Castellano JM, Navarro VM, Fernández-Fernández R, Nogueiras R, Tovar S, Roa J, Vazquez MJ, Vigo E, Casanueva FF, Aguilar E, Pinilla L, Dieguez C, Tena-Sempere M (2005) Changes in hypothalamic KiSS-1 system and restoration of pubertal activation of the reproductive axis by kisspeptin in undernutrition. Endocrinology 146:3917-3925.

Castellano JM, Navarro VM, Fernández-Fernández R, Roa J, Vigo E, Pineda R, Dieguez C, Aguilar E, Pinilla L, Tena-Sempere M (2006) Expression of hypothalamic KiSS-1 system and rescue of defective gonadotropic responses by kisspeptin in streptozotocin-induced diabetic male rats. Diabetes 55:2602-2610.

Castellano JM, Roa J, Luque RM, Dieguez C, Aguilar E, Pinilla L, TenaSempere M (2009) KiSS-1/kisspeptins and the metabolic control of reproduction: physiologic roles and putative physiopathological implications. Peptides 30:139-145.

Chen WP, Witkin JW, Silverman AJ (1989) Beta-Endorphin and gonadotropin releasing hormone synaptic input to gonadotropin releasing hormone neurosecretory cells in the male rat. J Comp Neurol 286:85-95.

Cowley MA, Pronchuk N, Fan W, Dinulescu DM, Colmers WF, Cone RD (1999) Integration of NPY, AGRP, and melanocortin signals in the hypothalamic paraventricular nucleus: evidence of a cellular basis for the adipostat. Neuron 24:155-163.

Cowley MA, Smart JL, Rubinstein M, Cerdán MG, Diano S, Horvath TL, Cone RD, Low MJ (2001) Leptin activates anorexigenic POMC neurons through a neural network in the arcuate nucleus. Nature 411:480-484.

d'Anglemont de Tassigny X, Fagg LA, Dixon JP, Day K, Leitch HG, Hendrick AG, Zahn D, Franceschini I, Caraty A, Carlton MB, Aparicio SA, Colledge WH (2007) Hypogonadotropic hypogonadism in mice lacking a functional Kiss1 gene. Proc Natl Acad Sci U S A 104:10714-10719.

de Roux N, Genin E, Carel JC, Matsuda F, Chaussain JL, Milgrom E (2003) Hypogonadotropic hypogonadism due to loss of function of the KiSS1derived peptide receptor GPR54. Proc Natl Acad Sci USA 100:10972-10976.

Dhillo WS (2008) Kisspeptin: a novel regulator of reproductive function. J Neuroendocrinol 20:963-970.

Dong HW, Hayar A, Callaway J, Yang XH, Nai Q, Ennis M (2009) Group I mGluR activation enhances $\mathrm{Ca}^{2+}$-dependent nonselective cation currents and rhythmic bursting in main olfactory bulb external tufted cells. J Neurosci 29:11943-11953.

Ducret E, Anderson GM, Herbison AE (2009) RFamide-related peptide-3, a mammalian gonadotropin-inhibitory hormone ortholog, regulates gonadotropin-releasing hormone neuron firing in the mouse. Endocrinology 150:2799-2804.

Dumalska I, Wu M, Morozova E, Liu R, van den Pol A, Alreja M (2008) Excitatory effects of the puberty-initiating peptide kisspeptin and group I metabotropic glutamate receptor agonists differentiate two distinct subpopulations of gonadotropin-releasing hormone neurons. J Neurosci 28:8003-8013.

Ehara T, Matsuoka S, Noma A (1989) Measurement of reversal potential of $\mathrm{Na}^{+}-\mathrm{Ca}^{2+}$ exchange current in single guinea-pig ventricular cells. J Physiol 410:227-249.

Elias CF, Aschkenasi C, Lee C, Kelly J, Ahima RS, Bjorbaek C, Flier JS, Saper CB, Elmquist JK (1999) Leptin differentially regulates NPY and POMC neurons projecting to the lateral hypothalamic area. Neuron 23:775-786.

Elmquist JK (2001) Hypothalamic pathways underlying the endocrine, autonomic, and behavioral effects of leptin. Physiol Behav 74:703-708.

Fernandez-Fernandez R, Martini AC, Navarro VM, Castellano JM, Dieguez C, Aguilar E, Pinilla L, Tena-Sempere M (2006) Novel signals for the integration of energy balance and reproduction. Mol Cell Endocrinol 254-255:127-132.

Franceschini I, Lomet D, Cateau M, Delsol G, Tillet Y, Caraty A (2006) Kisspeptin immunoreactive cells of the ovine preoptic area and arcuate nucleus co-express estrogen receptor alpha. Neurosci Lett 401:225-230.

Gottsch ML, Cunningham MJ, Smith JT, Popa SM, Acohido BV, Crowley WF, Seminara S, Clifton DK, Steiner RA (2004) A role for kisspeptins in the regulation of gonadotropin secretion in the mouse. Endocrinology 145:4073-4077.

Han SK, Gottsch ML, Lee KJ, Popa SM, Smith JT, Jakawich SK, Clifton DK, Steiner RA, Herbison AE (2005) Activation of gonadotropin-releasing hormone neurons by kisspeptin as a neuroendocrine switch for the onset of puberty. J Neurosci 25:11349-11356.

Heisler LK, Cowley MA, Kishi T, Tecott LH, Fan W, Low MJ, Smart JL, Rubinstein M, Tatro JB, Zigman JM, Cone RD, Elmquist JK (2003) Central serotonin and melanocortin pathways regulating energy homeostasis. Ann N Y Acad Sci 994:169-174.

Hentges ST, Nishiyama M, Overstreet LS, Stenzel-Poore M, Williams JT, Low MJ (2004) GABA release from proopiomelanocortin neurons. J Neurosci 24:1578-1583.

Herbison AE, de Tassigny X, Doran J, Colledge WH (2010) Distribution and postnatal development of Gpr54 gene expression in mouse brain and gonadotropin-releasing hormone neurons. Endocrinology 151:312-321.

Hill JW, Elmquist JK, Elias CF (2008) Hypothalamic pathways linking energy balance and reproduction. Am J Physiol Endocrinol Metab 294:E827-E832.

Huang H, van den Pol AN (2007) Rapid direct excitation and long-lasting enhancement of NMDA response by group I metabotropic glutamate receptor activation of hypothalamic melanin-concentrating hormone neurons. J Neurosci 27:11560-11572.

Ichimaru T, Mori Y, Okamura H (2001) A possible role of neuropeptide Y as a mediator of undernutrition to the hypothalamic gonadotropinreleasing hormone pulse generator in goats. Endocrinology 142:2489-2498.

Johnson MA, Tsutsui K, Fraley GS (2007) Rat RFamide-related peptide-3 stimulates $\mathrm{GH}$ secretion, inhibits $\mathrm{LH}$ secretion, and has variable effects on sex behavior in the adult male rat. Horm Behav 51:171-180.

Kalra PS, Bonavera JJ, Kalra SP (1995) Central administration of antisense oligodeoxynucleotides to neuropeptide Y (NPY) mRNA reveals the critical role of newly synthesized NPY in regulation of LHRH release. Regul Pept 59:215-220.

Kraft R (2007) The $\mathrm{Na}^{+} / \mathrm{Ca}^{2+}$ exchange inhibitor KB-R7943 potently blocks TRPC channels. Biochem Biophys Res Commun 361:230-236.

Kriegsfeld LJ, Mei DF, Bentley GE, Ubuka T, Mason AO, Inoue K, Ukena K, Tsutsui K, Silver R (2006) Identification and characterization of a gonadotropin-inhibitory system in the brains of mammals. Proc Natl Acad Sci U S A 10:2410-2415.

Lapatto R, Pallais JC, Zhang D, Chan YM, Mahan A, Cerrato F, Le WW, Hoffman GE, Seminara SB (2007) Kiss $1^{-1-}$ mice exhibit more variable hypogonadism than Gpr54 ${ }^{-1-}$ mice. Endocrinology 148:4927-4936.

Lee DK, Nguyen T, O’Neill GP, Cheng R, Liu Y, Howard AD, Coulombe N, Tan CP, Tang-Nguyen AT, George SR, O'Dowd BF (1999) Discovery of a receptor related to the galanin receptors. FEBS Lett 446:103-107.

Leranth C, MacLusky NJ, Shanabrough M, Naftolin F (1988) Immunohistochemical evidence for synaptic connections between pro-opiomelanocortinimmunoreactive axons and LH-RH neurons in the preoptic area of the rat. Brain Res 449:167-176.

Li C, Chen P, Smith MS (1999) Morphological evidence for direct interaction between arcuate nucleus neuropeptide Y (NPY) neurons and gonadotropin-releasing hormone neurons and the possible involvement of NPY Y1 receptors. Endocrinology 140:5382-5390.

Li XF, Kinsey-Jones JS, Cheng Y, Knox AM, Lin Y, Petrou NA, Roseweir A, Lightman SL, Milligan SR, Millar RP, O’Byrne KT (2009) Kisspeptin signalling in the hypothalamic arcuate nucleus regulates $\mathrm{GnRH}$ pulse generator frequency in the rat. PLoS One 4:e8334.

Liu X, Lee K, Herbison AE (2008) Kisspeptin excites gonadotropinreleasing hormone neurons through a phospholipase $\mathrm{C} /$ calciumdependent pathway regulating multiple ion channels. Endocrinology 149:4605-4614.

Luque RM, Kineman RD, Tena-Sempere M (2007) Regulation of hypothalamic expression of KiSS-1 and GPR54 genes by metabolic factors: analyses using mouse models and a cell line. Endocrinology 148:4601-4611. 
Matsuyama S, Ohkura S, Sakurai K, Tsukamura H, Maeda K, Okamura H (2005) Activation of melanocortin receptors accelerates the gonadotropinreleasing hormone pulse generator activity in goats. Neurosci Lett 383: 289-294.

Menyhért J, Wittmann G, Hrabovszky E, Keller E, Liposits Z, Fekete C (2006) Interconnection between orexigenic neuropeptide $\mathrm{Y}$ - and anorexigenic alpha-melanocyte stimulating hormone-synthesizing neuronal systems of the human hypothalamus. Brain Res 1076:101-105.

Messager S, Chatzidaki EE, Ma D, Hendrick AG, Zahn D, Dixon J, Thresher RR, Malinge I, Lomet D, Carlton MB, Colledge WH, Caraty A, Aparicio SA (2005) Kisspeptin directly stimulates gonadotropin-releasing hormone release via $G$ protein-coupled receptor 54. Proc Natl Acad Sci U S A 102:1761-1766

Mikkelsen JD, Simonneaux V (2009) The neuroanatomy of the kisspeptin system in the mammalian brain. Peptides 30:26-33.

Mikkelsen JD, Bentsen AH, Ansel L, Simonneaux V, Juul A (2009) Comparison of the effects of peripherally administered kisspeptins. Regul Pept 152:95-100.

Mounien L, Bizet P, Boutelet I, Vaudry H, Jégou S (2005) Expression of melanocortin MC3 and MC4 receptor mRNAs by neuropeptide Y neurons in the rat arcuate nucleus. Neuroendocrinology 82:164-170.

Niu CF, Watanabe Y, Ono K, Iwamoto T, Yamashita K, Satoh H, Urushida T, Hayashi H, Kimura J (2007) Characterization of SN-6, a novel $\mathrm{Na}^{+}$/ $\mathrm{Ca}^{2+}$ exchange inhibitor in guinea pig cardiac ventricular myocytes. Eur J Pharmacol 573:161-169.

Ohkura S, Takase K, Matsuyama S, Mogi K, Ichimaru T, Wakabayashi Y, Uenoyama Y, Mori Y, Steiner RA, Tsukamura H, Maeda KI, Okamura H (2009) Gonadotrophin-releasing hormone pulse generator activity in the hypothalamus of the goat. J Neuroendocrinol 21:813-821.

Palty R, Ohana E, Hershfinkel M, Volokita M, Elgazar V, Beharier O, Silverman WF, Argaman M, Sekler I (2004) Lithium-calcium exchange is mediated by a distinct potassium-independent sodium-calcium exchanger. J Biol Chem 279:25234-25240.

Parmentier R, Kolbaev S, Klyuch BP, Vandael D, Lin JS, Selbach O, Haas HL, Sergeeva OA (2009) Excitation of histaminergic tuberomamillary neurons by thyrotropin-releasing hormone. J Neurosci 29:4471-4483.

Pielecka-Fortuna J, Moenter SM (2010) Kisspeptin increases gammaaminobutyric acidergic and glutamatergic transmission directly to gonadotropin-releasing hormone neurons in an estradiol-dependent manner. Endocrinology 151:291-300.

Reid RL, Ling N, Yen SS (1981) Alpha-melanocyte stimulating hormone induces gonadotropin release. J Clin Endocrinol Metab 52:159-161.

Roa J, Aguilar E, Dieguez C, Pinilla L, Tena-Sempere M (2008) New frontiers in kisspeptin/GPR54 physiology as fundamental gatekeepers of reproductive function. Front Neuroendocrinol 29:48-69.

Rondini TA, Baddini SP, Sousa LF, Bittencourt JC, Elias CF (2004) Hypothalamic cocaine- and amphetamine-regulated transcript neurons project to areas expressing gonadotropin releasing hormone immunoreactivity and to the anteroventral periventricular nucleus in male and female rats. Neuroscience 125:735-748.

Roseberry AG, Liu H, Jackson AC, Cai X, Friedman JM (2004) Neuropeptide $\mathrm{Y}$-mediated inhibition of proopiomelanocortin neurons in the arcuatenucleus shows enhanced desensitization in ob/ob mice. Neuron 41:711-722.

Roseweir AK, Kauffman AS, Smith JT, Guerriero KA, Morgan K, PieleckaFortuna J, Pineda R, Gottsch ML, Tena-Sempere M, Moenter SM, Terasawa E, Clarke IJ, Steiner RA, Millar RP (2009) Discovery of potent kisspeptin antagonists delineate physiological mechanisms of gonadotropin regulation. J Neurosci 29:3920-3929.

Schwartz MW, Sipols AJ, Marks JL, Sanacora G, White JD, Scheurink A, Kahn SE, Baskin DG, Woods SC, Figlewicz DP (1992) Inhibition of hypothalamic neuropeptide $\mathrm{Y}$ gene expression by insulin. Endocrinology 130:3608-3616.

Schwartz MW, Woods SC, Porte D Jr, Seeley RJ, Baskin DG (2000) Central nervous system control of food intake. Nature 404:661-671.

Seeley R (2004) Our evolving understanding of peptides and the control of food intake. In: Neurobiology of food and fluid intake (Stricker EM, Woods SC, eds), pp 111-126. New York: Springer.

Seminara SB, Messager S, Chatzidaki EE, Thresher RR, Acierno JS Jr, Shagoury JK, Bo-Abbas Y, Kuohung W, Schwinof KM, Hendrick AG, Zahn D, Dixon J, Kaiser UB, Slaugenhaupt SA, Gusella JF, O’Rahilly S,
Carlton MB, Crowley WF Jr, Aparicio SA, Colledge WH (2003) The GPR54 gene as a regulator of puberty. N Engl J Med 349:1614-1627.

Shahab M, Mastronardi C, Seminara SB, Crowley WF, Ojeda SR, Plant TM (2005) Increased hypothalamic GPR54 signaling: a potential mechanism for initiation of puberty in primates. Proc Natl Acad Sci U S A 102:2129-2134.

Smith JT, Acohido BV, Clifton DK, Steiner RA (2006) KiSS-1 neurones are direct targets for leptin in the ob/ob mouse. J Neuroendocrinol 18: $298-303$.

Tachibana T, Sato M, Takahashi H, Ukena K, Tsutsui K, Furuse M (2005) Gonadotropin-inhibiting hormone stimulates feeding behavior in chicks Brain Res 1050:94-100.

Tachibana T, Masuda N, Tsutsui K, Ukena K, Ueda H (2008) The orexigenic effect of $\mathrm{GnIH}$ is mediated by central opioid receptors in chicks. Comp Biochem Physiol A Mol Integr Physiol 150:21-25.

Tena-Sempere M (2006) KiSS-1 and reproduction: focus on its role in the metabolic regulation of fertility. Neuroendocrinology 83:275-281.

Thompson EL, Patterson M, Murphy KG, Smith KL, Dhillo WS, Todd JF, Ghatei MA, Bloom SR (2004) Central and peripheral administration of kisspeptin-10 stimulates the hypothalamic-pituitary-gonadal axis. J Neuroendocrinol 16:850-858.

Tsunematsu T, Fu LY, Yamanaka A, Ichiki K, Tanoue A, Sakurai T, van den Pol AN (2008) Vasopressin increases locomotion through a V1a receptor in orexin/hypocretin neurons: implications for water homeostasis. J Neurosci 28:228-238.

Tsuruo Y, Kawano H, Kagotani Y, Hisano S, Daikoku S, Chihara K, Zhang T, Yanaihara N (1990) Morphological evidence for neuronal regulation of luteinizing hormone-releasing hormone-containing neurons by neuropeptide Y in the rat preoptic area. Neurosci Lett 110:261-266.

Tsutsui K (2009) A new key neurohormone controlling reproduction, gonadotropin-inhibitory hormone $(\mathrm{GnIH})$ : biosynthesis, mode of action and functional significance. Prog Neurobiol 88:76-88.

Tsutsui K, Saigoh E, Ukena K, Teranishi H, Fujisawa Y, Kikuchi M, Ishii S, Sharp PJ (2000) A novel avian hypothalamic peptide inhibiting gonadotropin release. Biochem Biophys Res Commun 275:661-667.

van den Pol AN, Yao Y, Fu LY, Foo K, Huang H, Coppari R, Lowell BB, Broberger C (2009) Neuromedin B and gastrin-releasing peptide excite arcuate nucleus neuropeptide $\mathrm{Y}$ neurons in a novel transgenic mouse expressing strong Renilla green fluorescent protein in NPY neurons. J Neurosci 29:4622-4639.

Wang M, Bianchi R, Chuang SC, Zhao W, Wong RK (2007) Group I metabotropic glutamate receptor-dependent TRPC channel trafficking in hippocampal neurons. J Neurochem 101:411-421.

Wang Q, Bing C, Al-Barazanji K, Mossakowaska DE, Wang XM, McBay DL, Neville WA, Taddayon M, Pickavance L, Dryden S, Thomas ME, McHale MT, Gloyer IS, Wilson S, Buckingham R, Arch JR, Trayhurn P, Williams G (1997) Interactions between leptin and hypothalamic neuropeptide $Y$ neurons in the control of food intake and energy homeostasis in the rat. Diabetes 46:335-341.

Ward DR, Dear FM, Ward IA, Anderson SI, Spergel DJ, Smith PA, Ebling FJ (2009) Innervation of gonadotropin-releasing hormone neurons by peptidergic neurons conveying circadian or energy balance information in the mouse. PLoS One 4:e5322.

Watanobe H, Schiöth HB, Wikberg JE, Suda T (1999) The melanocortin 4 receptor mediates leptin stimulation of luteinizing hormone and prolactin surges in steroid-primed ovariectomized rats. Biochem Biophys Res Commun 257:860-864.

Wu M, Zaborszky L, Hajszan T, van den Pol AN, Alreja M (2004) Hypocretin/orexin innervation and excitation of identified septohippocampal cholinergic neurons. J Neurosci 24:3527-3536.

Wu M, Dumalska I, Morozova E, van den Pol AN, Alreja M (2009) Gonadotropin inhibitory hormone inhibits basal forebrain vGluT2-gonadotropinreleasing hormone neurons via a direct postsynaptic mechanism. J Physiol 587:1401-1411.

Xu M, Hill JW, Levine JE (2000) Attenuation of luteinizing hormone surges in neuropeptide Y knockout mice. Neuroendocrinology 72:263-271.

Yaswen L, Diehl N, Brennan MB, Hochgeschwender U (1999) Obesity in the mouse model of pro-opiomelanocortin deficiency responds to peripheral melanocortin. Nat Med 5:1066-1070.

Zhang C, Roepke TA, Kelly MJ, Rønnekleiv OK (2008) Kisspeptin depolarizes gonadotropin-releasing hormone neurons through activation of TRPC-like cationic channels. J Neurosci 28:4423-4434. 